\title{
SOME PALEOZOIC SECTIONS IN ARIZONA AND THEIR CORRELATION.
}

\author{
By Frederick Leslie Ransome.
}

\section{PURPOSE AND SCOPE OF PAPER.}

During the last 16 years detailed geologic work has been done in a number of mining districts in Arizona, several reconnaissance reports have added to our knowledge of the geology of the State, and sections of Paleozoic and older rocks in the Grand Canyon and at Globe, Ray, Clifton, Tombstone, and Bisbee have been carefully studied; but hitherto the investigations in most of these fields have been unconnected by reconnaissance examinations of intervening areas. Realization of this lack of correlation led, in 1912 , to a preliminary reconnaissance of the country extending northwestward from Globe to Jerome, in the hope that light might thereby be thrown on the nature of the changes that connect the wellknown stratigraphic section of the Grand Canyon with the very different succession of beds at Globe. A visit to the Santa Catalina Range, northeast of Tucson, in company with Prof. C. F. Tolman, jr., who is preparing the Tucson folio for the United States Geological Survey, afforded an opportunity of partly closing the gap of terra incognita between Ray and Tombstone. Detailed work on the Ray quadrangle, the full results of which are not yet published, has supplied the materials for a much more accurate description of the geologic column in central Arizona than was heretofore possible, and similar work in the Tombstone district has extended the Bisbee section northward. Finally, some additional reconnaissance has been made of the Mazatzal Range and the Sierra Ancha.

The present paper includes (1) a brief introductory outline of the broad topographic features of the State, (2) a description of the full and very satisfactorily exposed geologic section of the Ray-Globe region, with less detailed accounts, in part abstracted from the literature, of other stratigraphic sections to the southeast and northwest, and (3) a discussion of the correlation of these sections from the Grand Canyon, in the northwestern part of the.State, to Bisbee, near the Mexican border.

The positions of the sections discussed may be seen by reference to the outline map ( $\mathrm{Pl}$. XXIV) and to the diagram accompanying the correlation chart (Pl. XXV, p. 136).

\section{TOPOGRAPHIC PROVINCES OF ARIZONA.}

The State of Arizona may conveniently be divided into three topographic regions-the plateau region, the mountain region, and the desert or bolson region. The plateau region, which has $£$ area of about 45,000 square miles, occupies the northeastern part of the State and drains generally northward through the Little Colorado and smaller streams into the Grand Canyon. The general altitude of this region, which is a portion of the great Colorado Plateau, ranges from 7,000 to over 8,500 feet. As Dutton graphically describes it,

Its strata are very nearly horizontal, and with the exception of Cataract Canyon and some of its tributaries it is not deeply scored. Low mesas, gently rolling and usually clad with an ample growth of pine, piñon, and cedar; broad and shallow valleys, yellow with sand or gray with sage, repeat themselves over the entire area.

Here and there the Kaibab (Pennsylvanian) limestone, the prevalent surface rock, is covered by flows of basalt or bears erosion remnants of younger strata, and above it, north of Flagstaff, rise the lofty extinct volcanoes of the San Francisco Mountains.

The southwestern limit of the plateau traverses the State in a general southeasterly direction from the Grand Wash Cliffs, near the eastern border of Nevada, to the New Mexico line, a few miles northeast of Clifton. ${ }^{1}$ This

1 Dutton, C. E., Tertiary history of the Grand Canyon district: U. S. Geol. Survey Mon. 2, p. 14, 1882. 
boundary along much of its course is a single bold cliff 2,000 feet or more in height, but elsewhere it is less definite or simple, owing to a distribution of the total difference in relief among a series of great topographic steps or to local accumulations of volcanic rocks, especially basalt. In general the outer or lower line of cliffs separates nearly horizontal and undisturbed strata on the northeast from faulted and tilted beds on the southwest, and locally, as along the Grand Wash Cliffs, this line is itself a fault scarp, more or less modified by erosion.

The Grand Wash Cliffs rise precipitously 3,000 feet or more above the plains to the west. According to Lee, ${ }^{1}$ pre-Cambrian granite is exposed at their base and the Redwall limestone forms their crest and the floor of the adjacent plateau. About 45 miles east of the Music Mountains a second gigantic step, that of the Aubrey Cliffs, north of Seligman, ${ }^{2}$ carries the geologic section nearly to the top of the Kaibab (Pennsylvanian) limestone, which forms the surface of the Coconino Plateau, south of the Grand Canyon. South of the Music Mountains there is another ample terrace in the ascent from the valleys of the mountain region to the Colorado Plateau-that of the Truxton Plateau. This bench, which lies between the Cottonwood and Aquarius cliffs to the west and the Yampai Cliffs and Juniper Mountains to the northeast, is described by $\operatorname{Le}^{3}$ as a granitic peneplain partly covered with volcanic rocks.

South of Ash Fork the continuity of the plateau escarpment is interrupted by flows of basalt that poured down from the plateau to the valley of the Verde, forming a slope that has been utilized by the Santa Fe, Prescott \& Phoenix Railway between Ash Fork and Jerome Junction. East of this railway and north of Jerome the edge of the plateau is in general a scarp (part of the Aubrey Cliff of Gilbert ${ }^{4}$ ) over 2,000 feet in total height, with deep reentrants and bold pinnacled promontories. East of Camp Verde a thick series of basaltic flows with associated tuffs has cov-

1 Lee, W. T., Geologic reconnaissance of a part of western Arizona: U. S. Geol. Survey Bull. 352, p. 19, pl. 1, 1908.

${ }^{2}$ See Darton, N. H., A reconnaissance of parts of northwestern New Mexico and northern Arizona: U. S. Geol. Survey Bull. 435, p. 8, pl. 1, 1910.

3 Op. cit., p. 21.

4 U. S. Geol. Surveys W. 100th Mer. Rept., vol. 3, p. 49, 1875. ered the edges of the nearly horizontal sedimentary rocks; but these beds appear again at the head of Fossil Creek and continue eastward past Payson in the great southwardfacing cliff that marks the descent of about 2,000 feet from the Mogollon Mesa to the Tonto Basin. From Fort Apache eastward to the New Mexico line the plateau boundary becomes less distinct. Erosion has partly destroyed its continuity, and vast accumulations of volcanic rock have obscured the original plateau surface.

The second topographic division, the mountain region, which adjoins the plateau region on the southwest, is essentially a broad zone of short nearly parallel ranges, among which are the Dragoon, Chiricahua, Whetstone, Pinaleno, Galiuro, Santa Catalina, Pinal, Superstition, Ancha, and Mazatzal, extending diagonally across the State from the southeast corner to Colorado River. The width of this zone may be taken as from 70 to 150 miles, but its southwest boundary is not susceptible of precise demarcation. Few of the individual ranges exceed 50 miles in length or 8,000 feet in altitude. Their general trend is almost northwest, but near the Mexican border it becomes more nearly north, and the mountain zone as a whole coalesces with a belt of north and south ranges that extends through New Mexico and borders the plateau region on the east.

Most of these ranges consist mainly of quartzites and limestones of Paleozoic or earlier age, resting with conspicuous unconformity upon granitic, gneissic, and schistose rocks. All these rocks are cut by later intrusives, especially by diabasic and monzonitic rocks, and are partly covered by flows of lava. Structurally these ranges are characterized by the dominant part played by faulting as compared with folding. The great copper deposits of Arizona, so far as they are known, are all, except that at Ajo, within this mountainous zone.

Adjoining the mountain region on the southwest is the third topographic division, the desert region, which also contains numerous short mountain ranges of prevalent northwesterly trend. In this region, however, most of the ranges are separated by broad desert plains underlain by fluviatile and lacustrine deposits of late geologic age, or by undulating granitic 


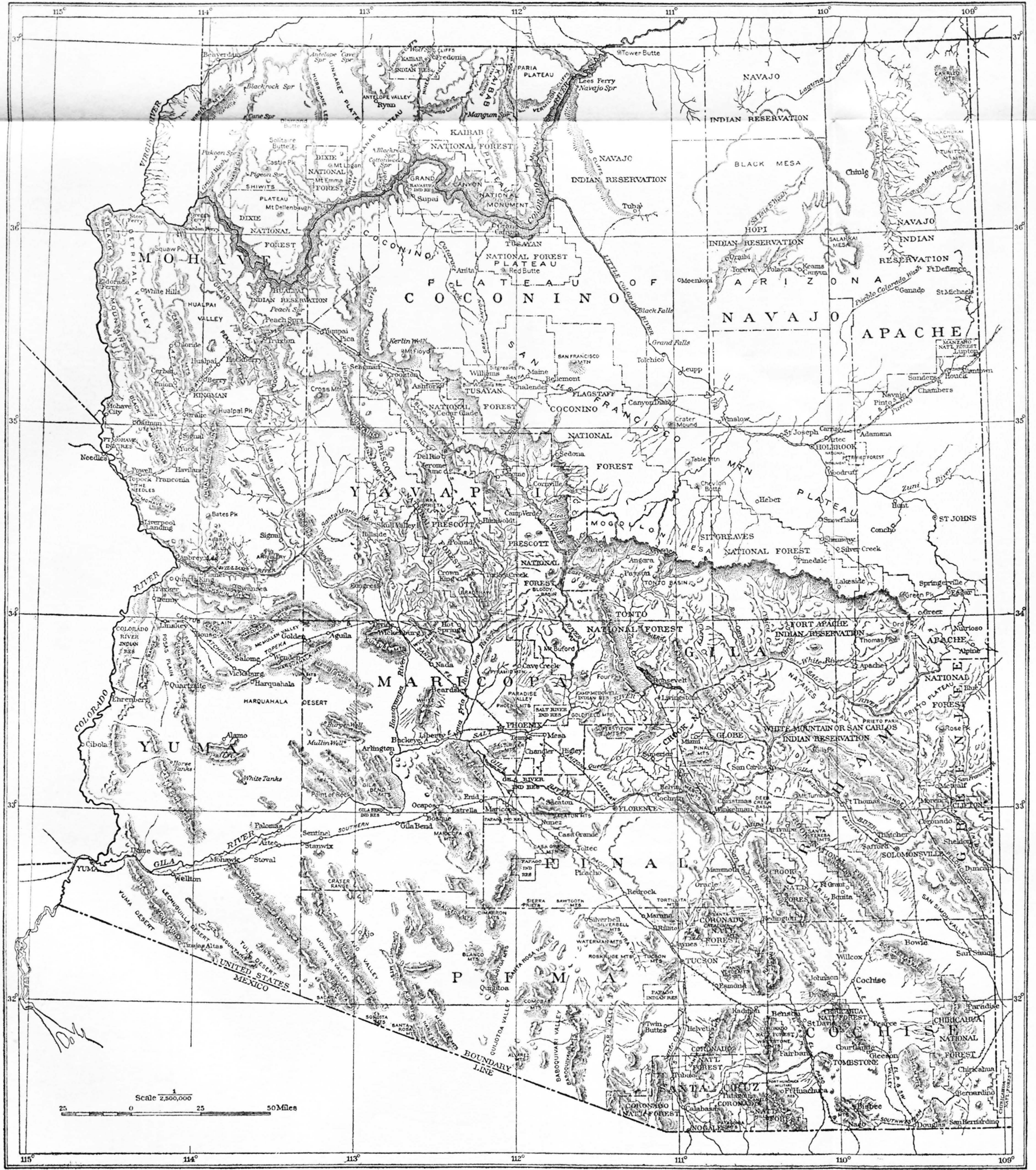

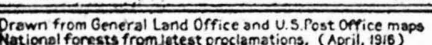


lowlands partly covered with gravels and flows of lava. ${ }^{1}$ The boundary between the mountain and desert regions is, as previously stated, indefinite but may provisionally be taken as a curved line extending from Nogales, on the Mexican frontier, past Tucson and Phoenix to Needles, near the California line. The main drainage lines of both regions are transverse to the trend of the ranges, the run-off finding its way through Gila and Williams rivers into the Colorado. The minor streams, many of them intermittent, occupy in general the valleys between the parallel ranges.

\section{RAY-GLOBẼ GEULOGIC SECTION. GENERAL IEATURES.}

The Ray and Globe quadrangles, as may be seen from the diagram on Plate XXV, are in south-central Arizona, and the Ray quadrangle lies immediately south of the Globe quadrangle. They include the Pinal Range and parts of the smaller Mescal, Dripping Spring, and Tortilla ranges. The relative positions of these ranges are shown in the outline map of Plate XXIV. The rocks are intricately faulted, the fault pattern being on an extraordinarily minute scale, and the stratified rocks have been extensively invaded by diabase. Nevertheless, excellent sections, of the kind illustrated in Plate XXIX (p. 141), may be studied in the Mescal Range and in many of the larger fault blocks of the Dripping Spring Range. The total thickness of the beds below the base of the Carboniferous limestone and above the preCambrian crystalline rocks is about 1,600 feet. The Carboniferous limestone is at least 1,000 feet thick and is limited above by a Mesozoic erosion surface. No evidence of angular unconformity has been detected within the Paleozoic sedimentary series in the Ray quadrangle, although the exposures are so good that any appreciable angular discordance could scarcely escape recognition.

\section{PINAL SCHIST.}

The Pinal schist and intrusive batholithic masses of granite and quartz-mica diorite are the fundamental rocks of the Ray-Globe region. The name Pinal schist was first applied in $1903^{2}$ to the pre-Cambrian schistose terrane

1 Antisell, Thomas, U. S. Pacific R. R. Expl., vol. 7, pt. 2, pp. 130-138, 1857.

2 Ransome, F. L., Geology and ore deposits of the Globe copper district, Ariz.: U. S. Geol. Survey Prof. Paper 12, p. 23, 1903. of the Globe quadrangle, the geographic term of the designation being derived from the Pinal Mountains, on whose slopes the schists are extensively exposed. As was then pointed out, these rocks probably correspond to what Blake $^{1} 20$ years earlier had called the "Arizonian slates," but as the geographic term of his name did not accord with the principles of nomenclature followed by the Geological Survey and as his lithologic term was not appropriate for crystalline schists, that designation could not well be retained. Since the publication of the Globe report the name Pinal schist has been applied to the pre-Cambrian crystalline schists of the Clifton-Morenci ${ }^{2}$ and Bisbee ${ }^{3}$ districts. This formation has of late years attained economic importance as the principal country rock of the disseminated copper deposits at Ray and Miami.

Most of the Pinal schist is light gray to blue-gray in color and has a more or less satiny luster on the cleavage surface. In texture it ranges from cryptocrystalline slaty sericitic schist through fine-granular fissile rocks to imperfectly cleavable, coarsely crystalline quartzmuscovite schist carrying andalusite or sillimanite. The coarsely crystalline varieties occur chiefly in the vicinity of granitic intrusive masses and grade into the less intensely metamorphosed varieties that make up the bulk of the formation and are characteristic of most of the exposures in the Ray quadrangle.

In the vicinity of Ray and west of that town a considerable part of the schist is a gray finegrained, moderately fissile rock that has the unmistakable aspect of a squeezed and metamorphosed sandstone. Thin sections of this variety, seen under the microscope, show rotund but irregular grains of quartz as much as 5 millimeters in diameter in a groundmass consisting chiefly of quartz and sericite. The large quartz grains show the effects of granulation with more or less recrystallization under pressure.

Associated with those schists that are clearly of sedimentary origin are very subordinate masses of greenstone schist and other varieties that were originally igneous material.

1 Blake, W. P., Geology of the Silver King mine: Eng. and Min. Jour., vol. 35 , pp. 238-239, 1883.

${ }^{2}$ Lindgren, Waldemar, The copper deposits of the Clifton-Morenci district, Ariz.: U. S. Geol. Survey Prof. Paper 43, p. 56, 1905.

3 Ransome, F. L., The geology and ore deposits of the Bisbee quadrangle, Ariz.: U. S. Geol. Survey Prof. Paper 21, p. 24, 1904. 
SCANLAN CONGLOMERATE.

At the base of the sedimentary column at Ray (see Pl. XXV) is the Scanlan conglomerate, first described in the Globe report, where it was said to be from 1 to 6 feet thick and composed of imperfectly rounded pebbles of vein quartz with scattered flakes of schist held in a pink arkosic matrix. The Scanlan conglomerate is locally the most variable of all the Paleozoic formations, both in constitution and in thickness. It was evidently formed, with little transportation, from the materials that the waves of an advancing sea found lying on a well-worn ancient surface of low relief. Areas of schist were littered with fragments of white vein quartz, and the upper parts of granitic masses were deeply disintegrated. Consequently the basal conglomerate where it rests on the Pinal schist is composed chiefly of imperfectly rounded pebbles of quartz in a matrix of small particles of schist, grains of quartz, and flakes of mica; where it rests on granite or quartzmica diorite the pebbles are also mostly quartz, but the matrix is arkosic and the layers of pebbles may be associated with deposits of arkose that in many places merge imperceptibly with the underlying massive rock or the overlying Pioneer shale. These two varieties of the conglomerate, however, are connected by transition facies. The thickness of the formation varies widely from place to place.

In some localities the base of the Pioneer shale may be marked only by a few sparsely distributed pebbles or the Scanlan conglomerate may not be recognizable at all. In others the conglomerate attains a thickness of fully 15 feet and carries abundant well-rounded pebbles, including a few of quartzite derived from some ancient formation that is not now exposed in this region. Above this welldefined bed, which locally resembles the younger Barnes conglomerate, and under the typical Pioneer shale is a coarse arkosic sandstone from 15 to 30 feet thick. Similar arkosic material accompanies the Scanlan conglomerate in other localities and marks a change in the conditions of deposition by which fine material was laid down instead of coarse. In the Barnes Peak section, in the northwestern part of the Globe quadrangle, the lower 25 feet of the Pioneer shale, above the Scanlan conglomerate, is sandy and arkosic.
PIONEER SHALE.

In the Globe report the name Pioneer shale was given to a series of shaly beds that overlie the Scanlan conglomerate and underlie the Barnes conglomerate. The typical section is that exposed on the northeast slope of Pioneer Mountain.

In most places the Pioneer formation consists of dark reddish-brown, more or less arenaceous shales composed largely of fine arkosic detritus with little or no calcareous material. In somt beds fragments of pink feldspar are easily recognizable with the unaided eye, and as a rule the shales toward their base grade into arkosic grits. These arkosic basal beds are well developed in the Apache Mountains, just northeast of the Globe quadrangle, where they attain a thickness of approximately 175 feet. Up to a horizon 75 feet above the granite the individual beds are thick, but above that thinner beds appear and these grade upward into the shale. Abundant round or elliptical spots, light buff or greenish in color, caused by local reduction and removal of the ferruginous pigment, are highly characteristic of the Pioneer shale, and in the absenoe of clear structural relations serve to distinguish that formation from certain similar beds in the stratigraphically higher Dripping Spring quartzite. Surfaces of fresh fracture generally sparkle with minute flakes of white mica.

Although the Pioneer shale is soft in comparison with the conglomerates and quartzites and weathers into smooth slopes, it is nevertheless a well-indurated, firm, and in places not very fissile rock. The general color of the formation as seen on the hill slopes is dark red, maroon, chocolate, or dull purplish gray.

In the Globe report the average thickness of the Pioneer shale was given as 200 feet, which is about the thickness at Pioneer, in the northeastern part of the Ray quadrangle. In the ravine west of Hackberry Spring, in the southwestern part of the Ray quadrangle, the shale is 100 feet thick. The average thickness for that quadrangle is accordingly estimated at about 150 feet. The Pioneer shale so far as known is not fossiliferous and presents no characteristics that mark it indubitably as marine or fluviatile in origin. It is believed to be marine and to have been deposited in shallow water. No mud cracks have been observed in it. 


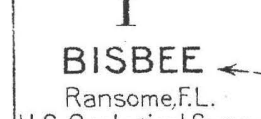

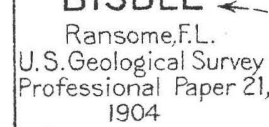

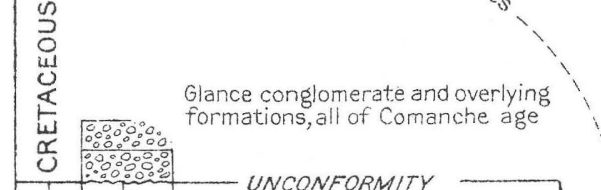

II

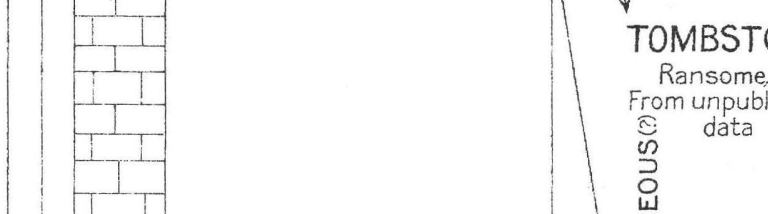

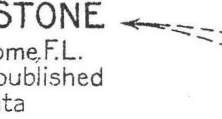

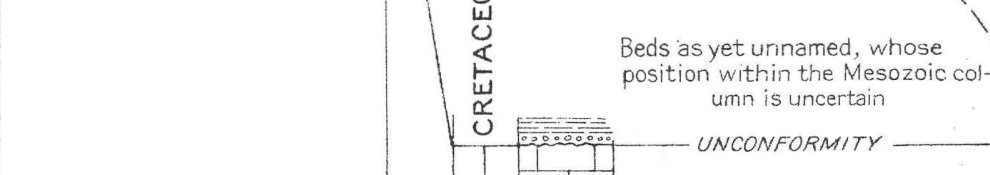

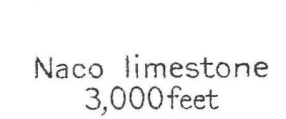

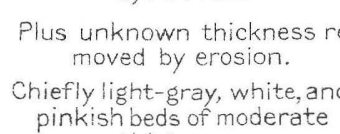

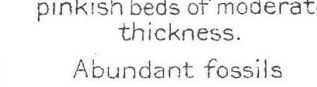

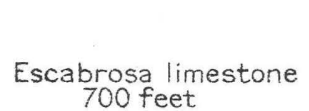

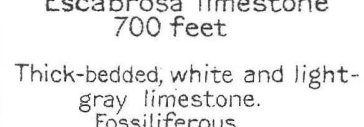

Martin limestone
340 freet

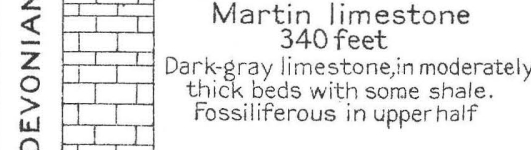

Abrigof limestone

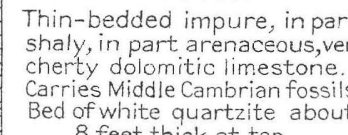

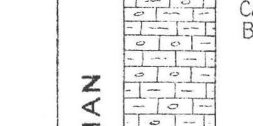

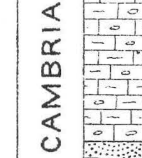

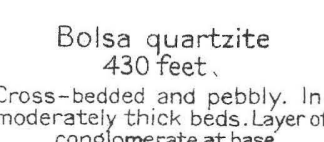

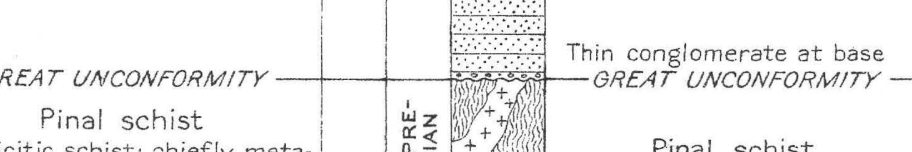

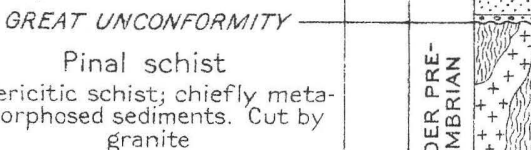

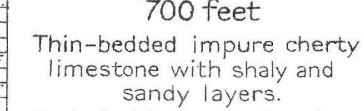

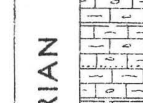

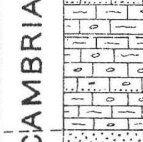

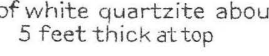

Bolsa quartzite
444 foet

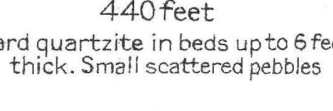

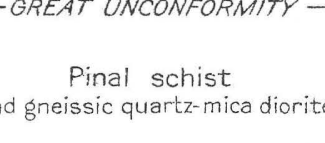

GENERALIZED COLUMNAR SECTIONS

\section{PALEOZOIC STRATA OF ARIZONA}

FROM MEXICO TO THE GRAND CANYON

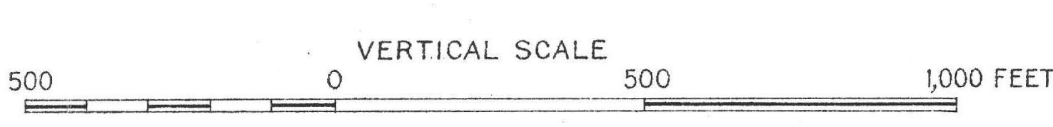

GLOBE AND RAY

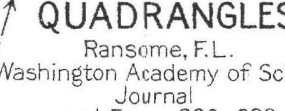

瓷

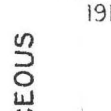

Escabros, limestone
5od ffeet

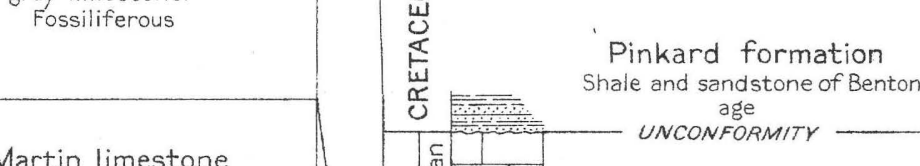

Tule Spring limeston

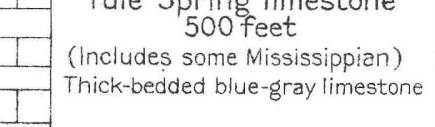

Abrigglimestone
DOo FEET

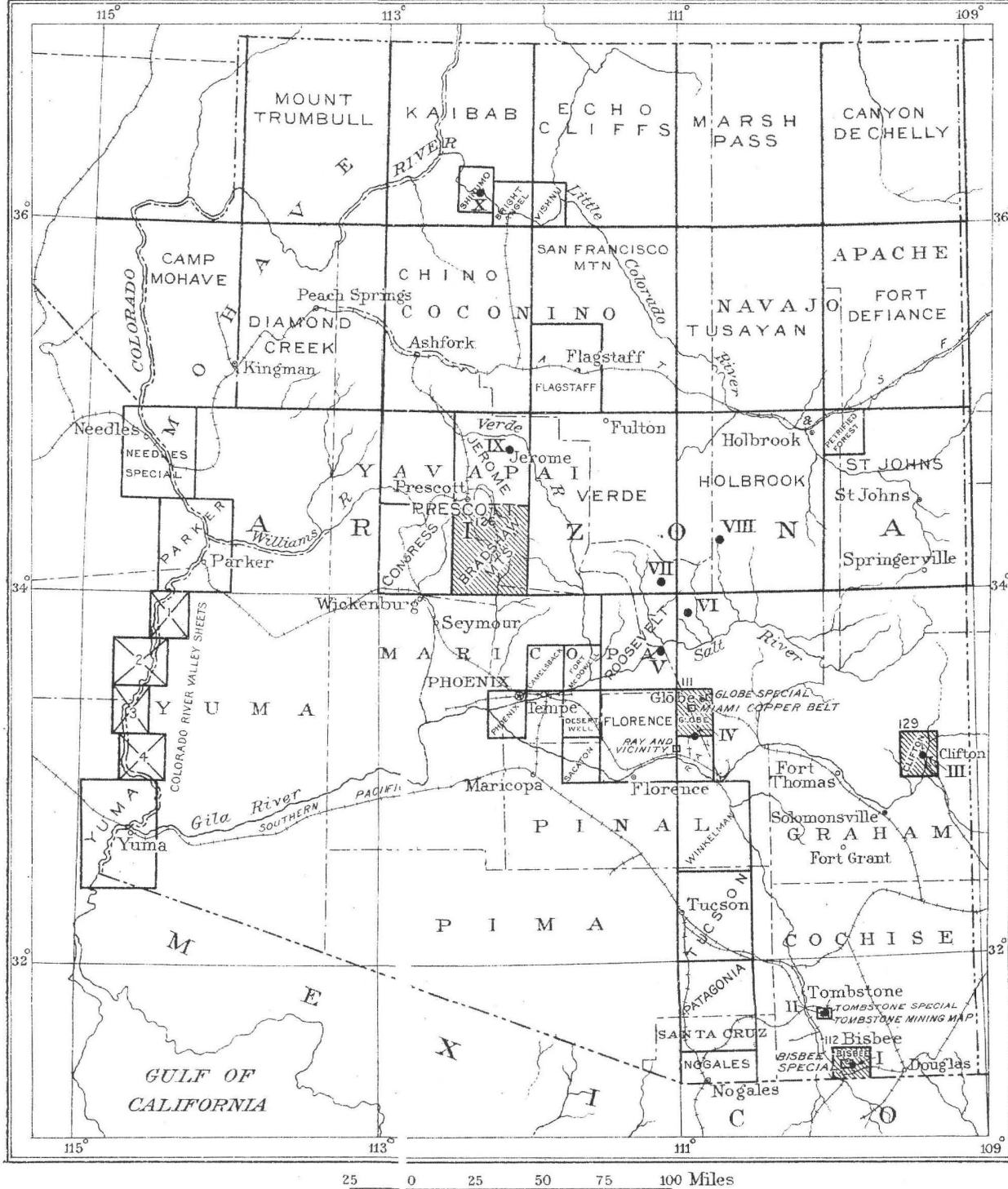

INDEX MAP SHOWING LOCATINN OF SECTIONS MEASURED AND RELLTION
OF LOCALITIES VISTITES TO PUBLLSHED TOPOGRAPHIC AND

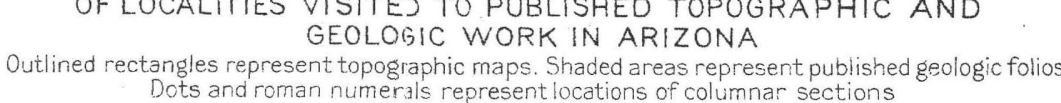

\section{VI}

$\forall$ SOUTHERN PART
OF THE

SIERRA ANCHA

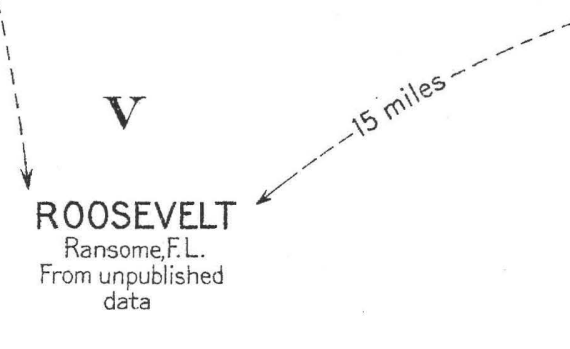

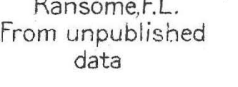

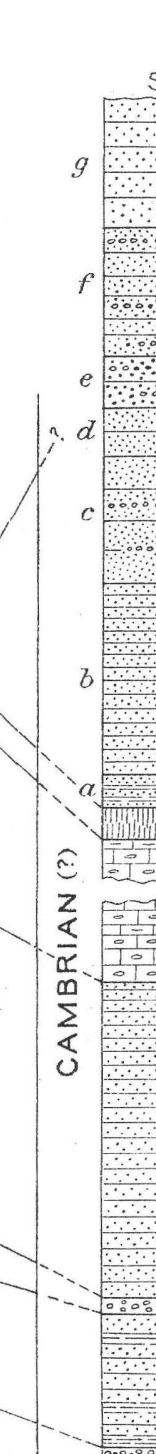

JEROME REGION Ransome F.L.
From unpubished
data

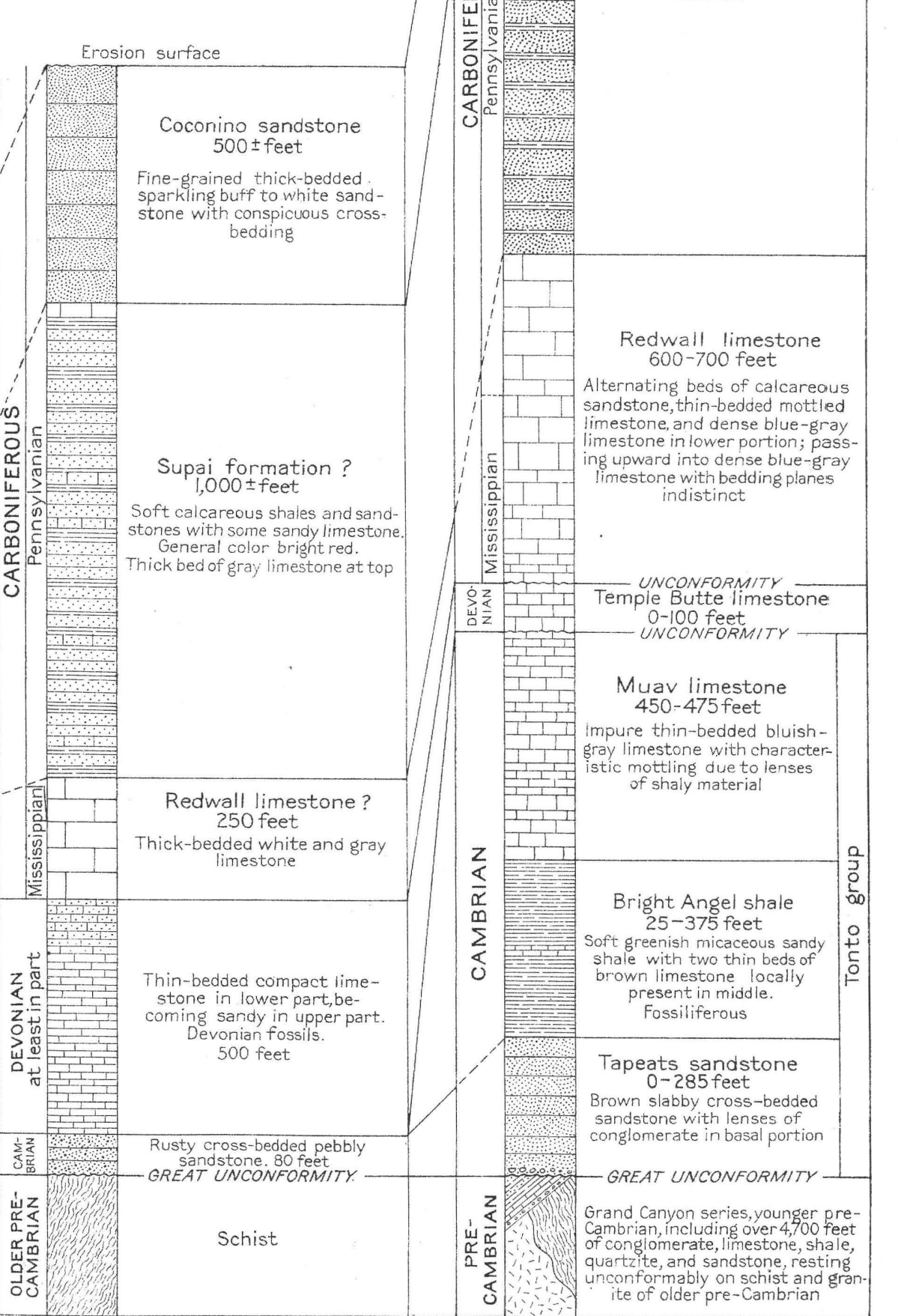

GRAND CANYON

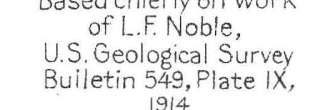

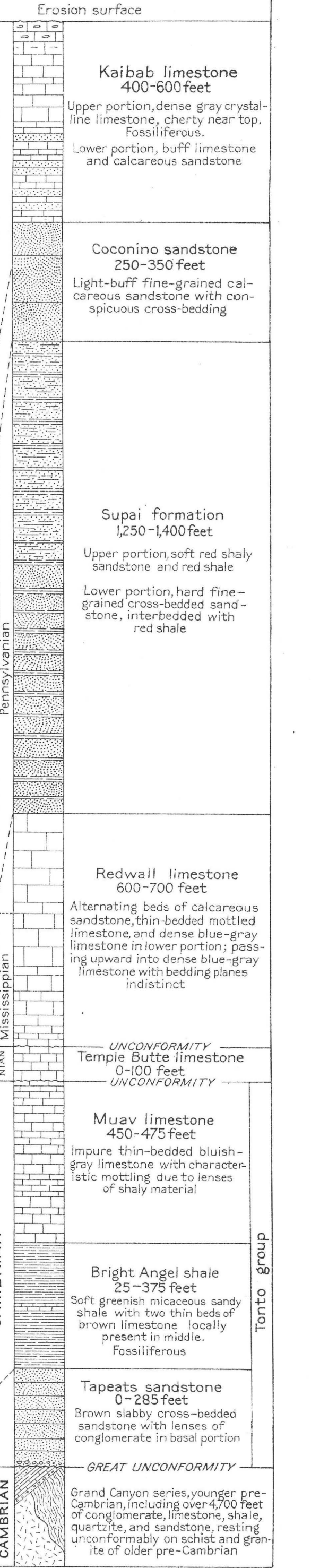


BARNES CONGLOMERATE.

The Barnes conglomerate lies stratigraphically above the Pioneer shale and below the Dripping Spring quartzite. The formation was first described in the Globe report and was named from Barnes Peak, in the northwestern part of the Globe quadrangle, where it is from 10 to 15 feet thick. There is no apparent unconformity either above or below the conglomerate, although the abrupt change from a fine shale to a deposit of coarse pebbles is indicative of so extensive a modification of the conditions of erosion and sedimentation under which the shales accumulated as would seem to demand a notable unconformity of contemporaneous origin somewhere within the region of deposition.

In its typical development, as near Pioneer Mountain or on Silver Creek, in the Ray quadrangle, the Barnes conglomerate consists of smooth pebbles of white quartz and hard vitreous quartzite in an arkosic matrix. The pebbles are generally 6 inches or less in diameter but in a few places there are some as much as 8 inches in diameter. Although smoothly rounded, the pebbles are not globular but are flattened ellipsoids or round-edged disks. They are composed only of the most durable materials and doubtless passed through long and varied processes of attrition before they came to rest in the Barnes conglomerate. On the whole, such meager evidence as is obtainable appears to indicate that the conglomerate represents stream action rather than littoral or marine action. The formations that supplied the quartzitic material to the conglomerate, as will be shown later, are exposed north of Roosevelt, in the Sierra Ancha and the Mazatzal Range.

In some places the pebbles, which generally lie with their flat sides roughly parallel to the bedding planes, are in contact and the proportion of arkosic matrix is correspondingly small; in other places the matrix predominates. As a rule, the pebbles become larger and more abundant toward the south, although the gradation is probably not wholly regular. Thus at Barnes Peak the average diameter of the pebbles is 3 or 4 inches and the thickness of the formation from 10 to 15 feet. In the vicinity of El Capitan Mountain, in the Mescal Range, pebbles 6 inches in diameter are abundant, the average size is probably a little larger than at Barnes Peak, and the thickness of the formation is from 15 to 20 feet. At the north end of the Dripping Spring Range the conglomerate is rather variable. A small exposure about $1 \frac{1}{3}$ miles north of Walnut Spring shows thin bands of pebbles associated with pinkish arkose and gray shale. The pebbles, which are ohiefly white quartz and not very well rounded, rarely exceed 2 inches in diameter and not any over 3 inches were seen. About 2 miles northwest of Walnut Spring the whole formation is from 10 to 12 feet thick, but the arkosic matrix is much more abundant than the pebbles, which although not uniformly distributed are, as a rule, most numerous near the base. The lower part of the bed thus presents in some places the aspect of the typical Barnes conglomerate, but the upper part is distinguishable from the overlying quartzite only by the oocurrenoe within it of a few small and scattered pebbles.

Northeast of Tam O'Shanter Peak, on the other hand, the conglomerate is about 40 feet thick and consists of chiefly smooth, rounded pebbles that are generally in contact with one another, with just enough matrix to fill the interstices. Some of the pebbles are as much as 10 inches in diameter, but most of them are under 6 inches. In the Tortilla Range, south of Kelvin, the conglomerate is about 55 feet thick and contains abundant characteristic pebbles 8 inches or less in diameter.

The arkosic matrix of the conglomerate is generally similar to the material of the overlying Dripping Spring quartzite, although perhaps a little coarser. It varies in hardness, but as a rule all the constituents of the conglomerate are cemented by silica into a hard and durable rock in which fractures traverse pebbles and matrix alike. A very characteristic feature of the Barnes conglomerate is the presence in the matrix of small fragments of vermilion-red chert or jasper as much as an inch or so in diameter.

A view of the upper part of the Barnes conglomerate as exposed on El Capitan Creek, in the northeastern part of the Ray quadrangle, is shown in Plate XXVI, $C$.

\section{DRIPPING SPRING QUARTZITE.}

The Dripping Spring quartzite lies conformably on the Barnes conglomerate and under the 
Mescal limestone.1 Approximately the lower third of the formation consists of hard finegrained arkosic quartzites, which, as seen in natural sections, show no very definite division into distinct beds but do exhibit a pronounced striping, due to the alternation of dull-red and dark-gray or nearly black bands parallel with the planes of stratification. These bands as a rule are less than 1 foot thick and give a generally thin-bedded aspect to this portion of the formation, as may be seen from Plate XXVII, $B$, although the illustration fails to show the contrasting tints of the bands. About midway between the top and bottom of the formation the striped beds are succeeded by fairly massive beds, as much as 6 feet thick, of even-grained buff or pinkish quartzite associated with flaggy variegated red, brown, and gray beds and with some layers of gray and reddish shales suggestive of the Pioneer shale.

In the upper part of the formation the beds become thin, flaggy, and rusty, with a tendency to grade into the Mescal limestone.

The sand which became the Dripping Spring quartzite was deposited in shallow water and was at times exposed to the air, as may be seen from the ripple marks, sun cracks, and fossil worm casts visible on the surface of the beds. The deposit is tentatively regarded as of delta origin. It is composed throughout of fine material, and contains no pebbles, so far as known. This feature and the banding of its lower beds serve throughout the Ray quadrangle to distinguish this quartzite from the pebbly cross-bedded Troy quartzite, to be described later.

Where almost vertically upturned in the Tortilla Range the Dripping Spring quartzite appears to be about $500^{\circ}$ feet thick, but the presence of intrusive diabase detracts a little from the reliability of this measurement, as movements during the intrusion may have increased the apparent thickness. Southwest of Pioneer Mountain, where the whole of the quartzite seems to be exposed without noticeable faulting, the thickness obtained by calculation from the width of the outcrop as mapped, the average dip of the beds, and the general angle of topographic slope is between 450 and

\footnotetext{
1 This is a redefinition of Dripping Spring quartzite as the name was originally used in the Globe quadrangle. The reasons for the change have been published (Min. and Sci. Press, vol. 102, pp. 747-748, 1911) and are summarized on pages 143-144 of the present paper.
}

500 feet. At Barnes Peak, in the Globe quadrangle, the thickness was estimated at 400 feet. The average thickness for the Ray quadrangle is taken at 450 feet, which is probably under rather than above the truth.

\section{MESCAL LIMESTONE.}

The Mescal limestone was first recognized as a distinct formation in the course of mapping the Ray quadrangle and is named from the Mescal Mountains, where it is well exposed. Stratigraphically it is limited below by the Dripping Spring quartzite and above by the Troy quartzite. Some fragments of this formation, most of them intimately associated with intrusive diabase, occur in the Globe quadrangle, but when the report on that area was prepared these masses of strata were supposed to be somewhat metamorphosed portions of the thin Devonian beds in the lower part of the "Globe limestone."

In the Ray quadrangle also the Mescal limestone and the diabase are closely associated. Lying between the two heavy quartzitic formations, the thin-bedded dolomitic limestone proved an easy path for the invading diabase magma and retains little of its former continuity. In the development of the topography the diabase tends to wear down into swales and hollows, and an extended view over one of these depressions shows the generally olivetinted surface characteristic of diabase areas, varied by blotches of white that represent included blocks of the Mescal limestone, some of which are nearly a quarter of a square mile in area. Other portions of the formation rest in their original position on the Dripping Spring quartzite, and the diabase lies in igneous contact above them. Still others crop out along the bases of cliffs formed by the Troy quartzite and lie above the intruded diabase. Rarely the limestone lies unbroken between the two quartzites.

The Mescal limestone is composed of thin beds that have a varied range of color, but are persistently cherty, the siliceous segregations as a rule forming irregular layers parallel with the bedding planes. On weathered surfaces these layers stand out in relief and give to the limestone the rough, gnarled banding that is its most characteristic feature. The usual appearance of the Mescal limestone on outcrop- 


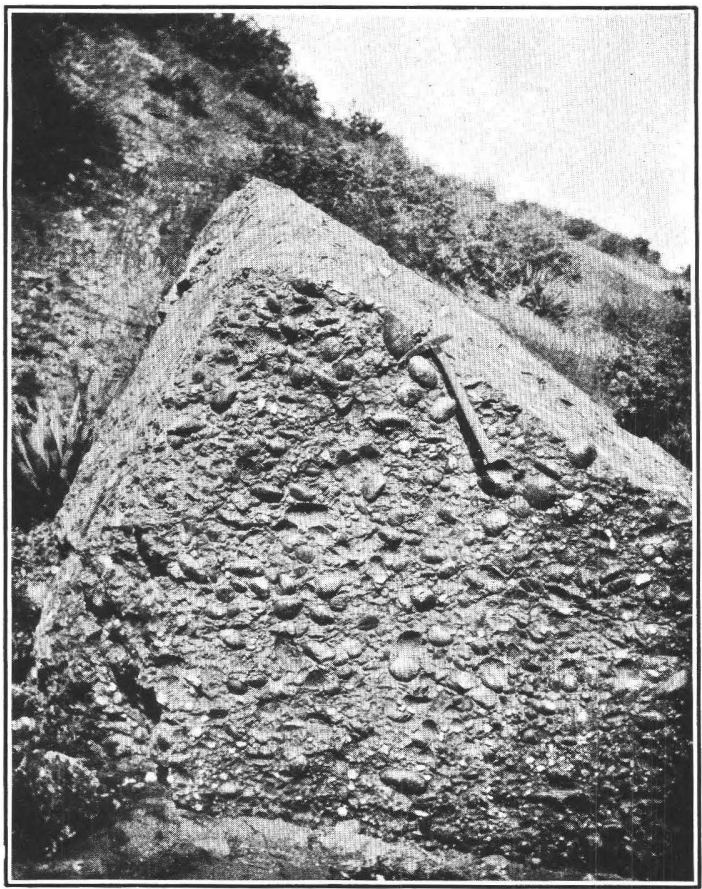

A. BARNES CONGLOMERATE AT SOUTH END OF PINAL RANGE, GLOBE QUADRANGLE, ARIZ.

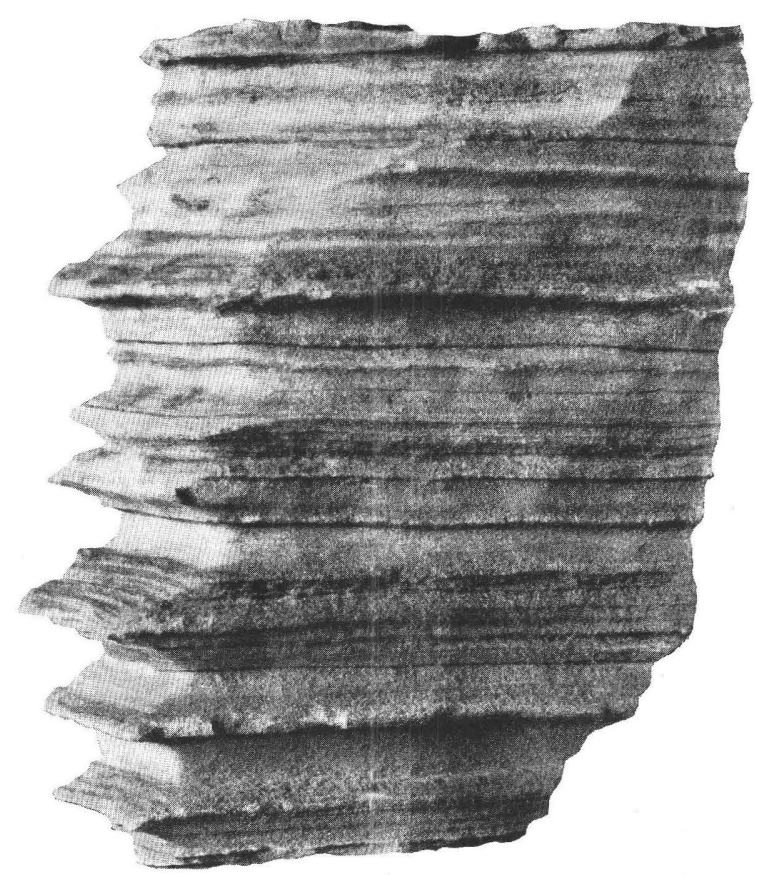

B. MESCAL LIMESTONE ON EL CAPITAN CREEK, MESCAL RANGE, RAY QUADRANGLE, ARIZ., SHOWING EFFECT OF WEATHERING.

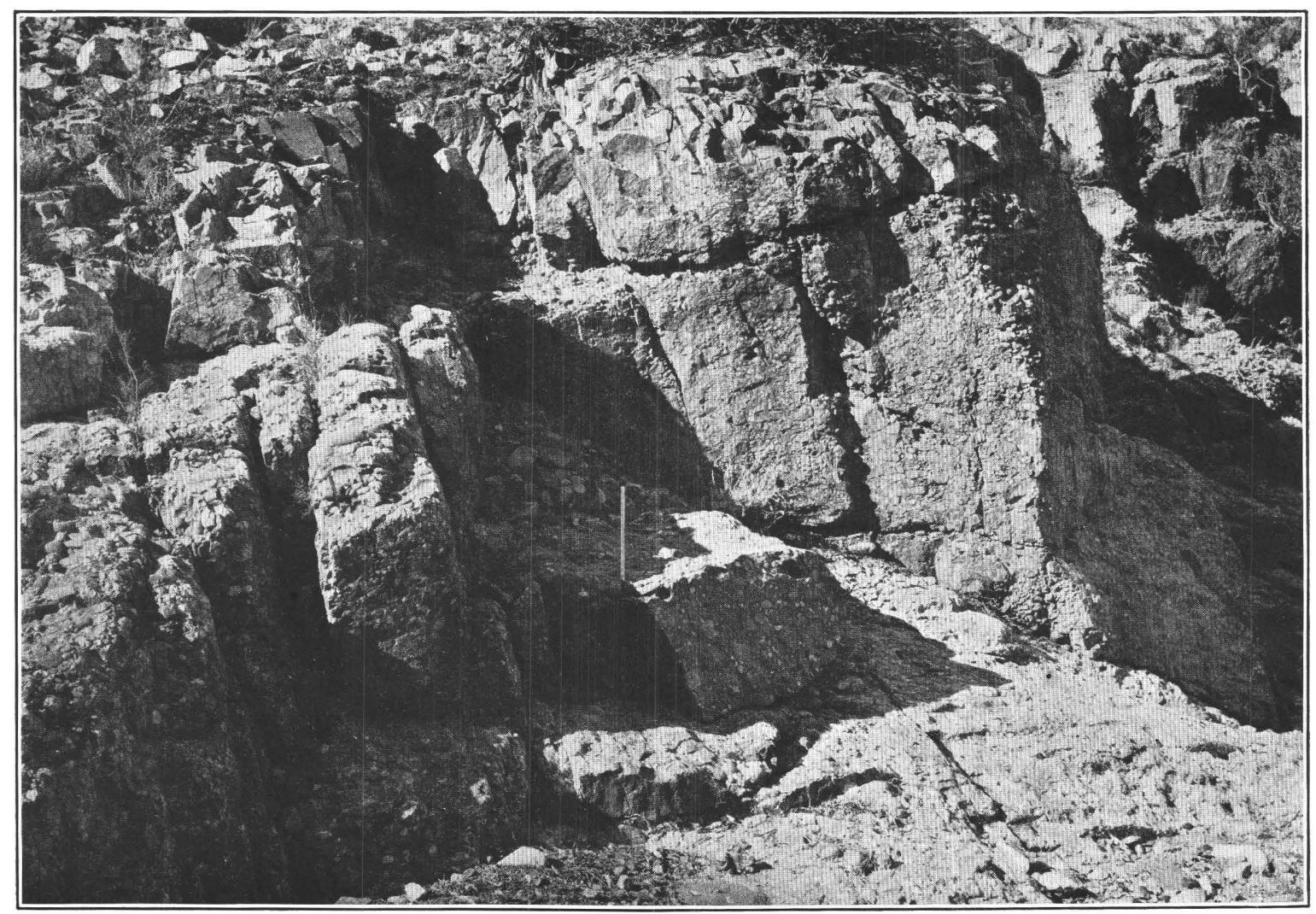

C. BARNES CONGLOMERATE, EL CAPITAN CREEK, ARIZ. 


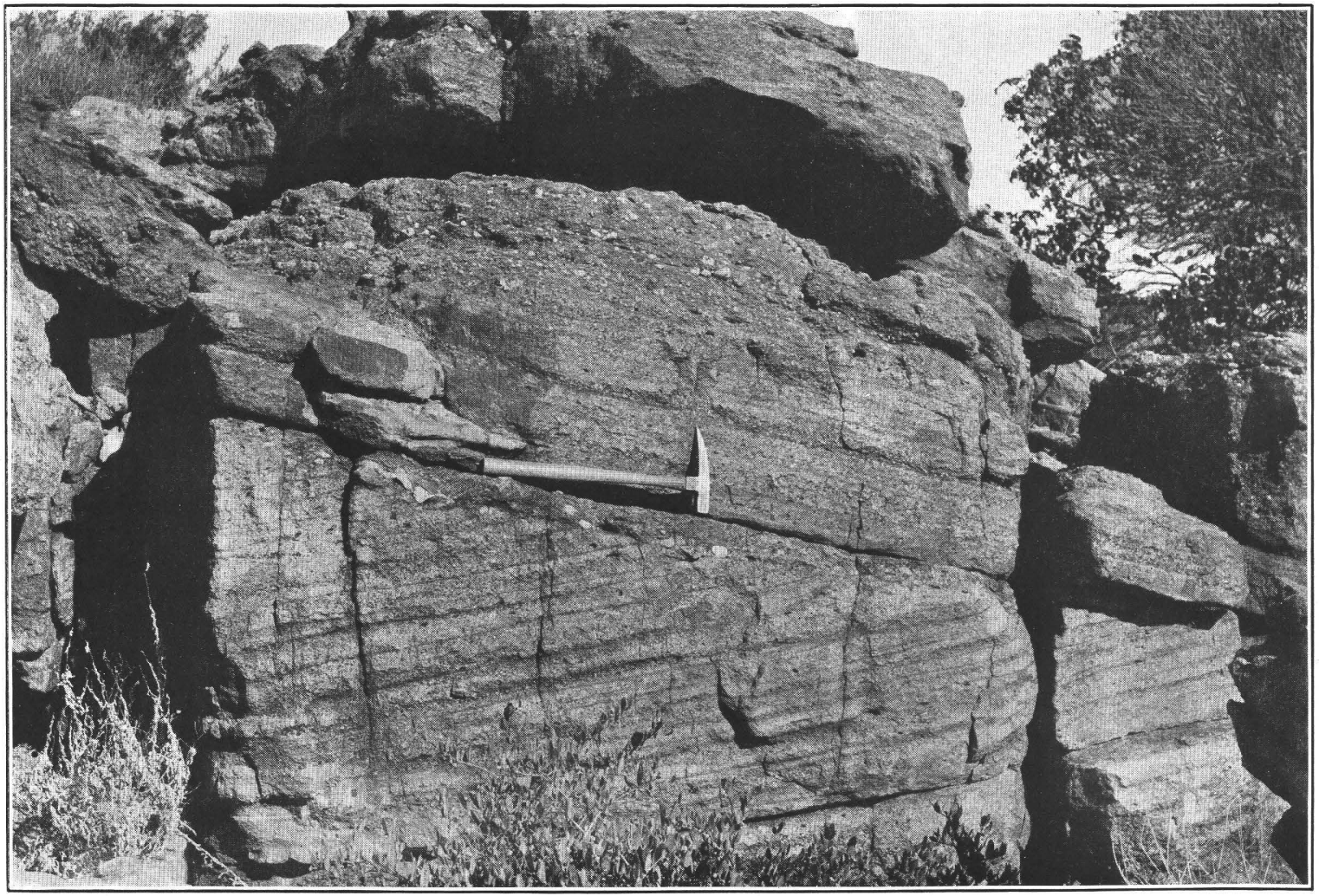

A. CROSS-BEDDED PEBBLY TROY QUARTZITE, DRIPPING SPRING RANGE.

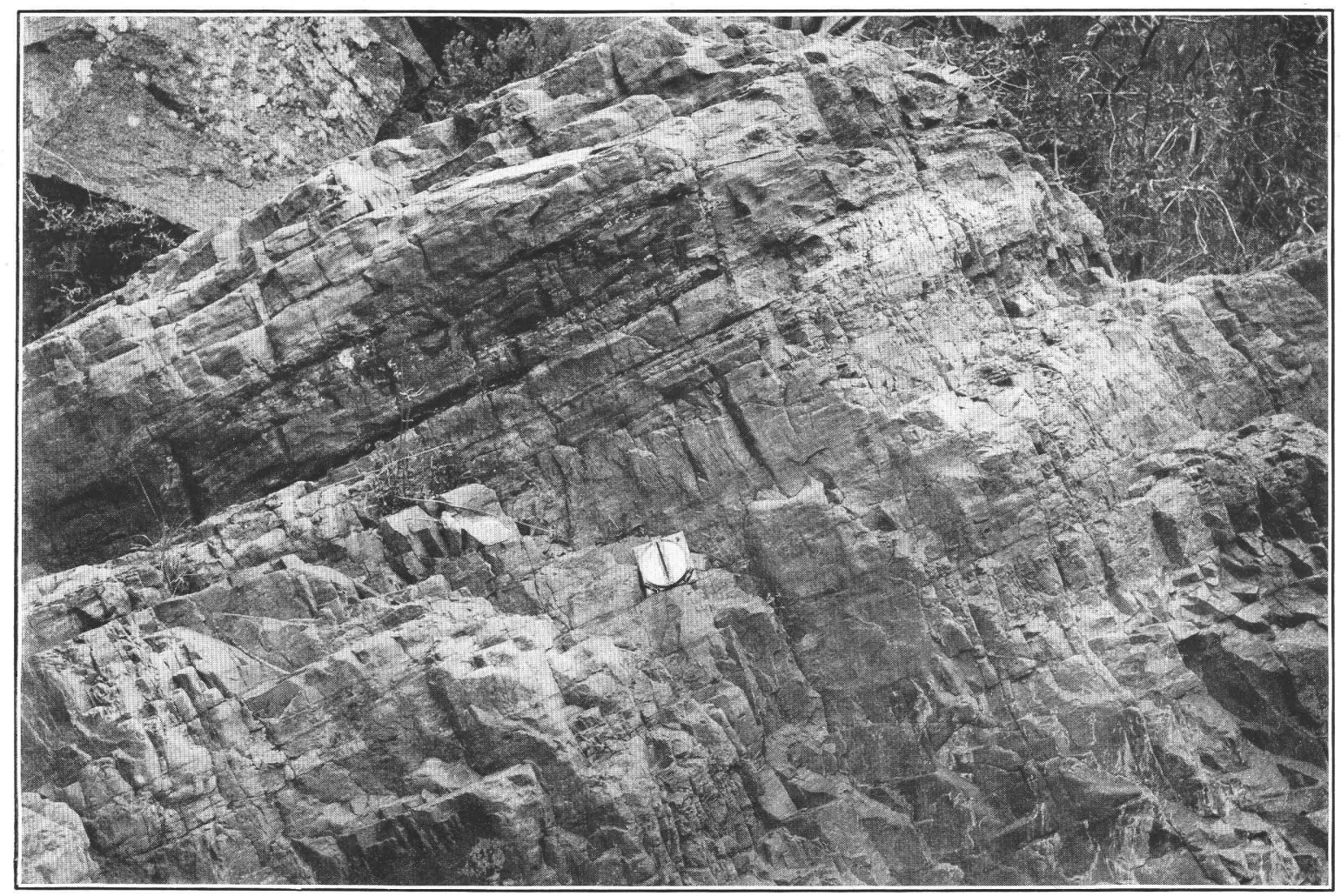

B. BANDED DRIPPING SPRING QUARTZITE, MESCAL RANGE, 1 MILE SOUTH OF PIONEER. 
ping edges is shown in Plate XXVIII. The general hue of the formation is gray or white, but some beds are yellow, buff, brown, or rusty. In some localities the rough, gnarled strata are accompanied by others containing thin regular buff and gray layers whose differences in chemical composition in conjunction with the dissolving action of atmospheric water gives rise to such natural ornamentation as is illustrated in Plate XXVI, $B$.

Between the limestone and the overlying Troy quartzite is a layer of decomposed vesicular basalt whose maximum observed thickness is 100 feet. Although the basalt is in places much thinner than this, the flow was apparently coextensive with the Mescal limestone throughout the Ray and Globe quadrangles. Where the basalt is in contact with the later intrusive diabase distinction between the two is difficult in the absence of good exposures, and in the earlier work in the Globe quadrangle the altered vesicular basalt was supposed to be merely a contact modification of the diabase.

A section of the Mescal limestone with the overlying basalt flow, as exposed on the east side of El Capitan Canyon, is given below. The thicknesses stated are approximate.

\section{Section of the Mescal limestone.}

Troy quartzite.

Vesicular basalt

4. Striped buff and gray dolomitic limestone weathering sharp channels and ridges, as illustrated in Plate XXVI, $B$

3. Very rough cherry dolomitic limestone with no distinct division into beds. Weathers with gnarly dark rusty-brown surface.................

2. Gnarled, knotty cherty limestone, mostly dolomitic, in beds as much as 2 feet thick. Some beds light gray and some dark brown. Shaly partings.............................. 125

1. Thin impure shaly limestone, with perhaps some dolomite. Splits into thin leaves. Mostly light gray. ............................... 50 Dripping Spring quartzite.

The analysis of a sample from division 2 of the foregoing section is as follows:

Partial chemical analysis of Mescal limestone.

[George Steiger, analyst.]

$\mathrm{SiO}_{2} \ldots \ldots \ldots \ldots \ldots \ldots \ldots \ldots \ldots \ldots . .29 .93$

$\mathrm{Al}_{2} \mathrm{O}_{3} \ldots \ldots \ldots \ldots \ldots \ldots \ldots \ldots \ldots \ldots \ldots \ldots \ldots \ldots \ldots \ldots \ldots . .42$

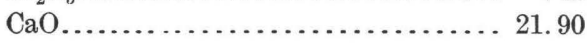

$\mathrm{MgO} \ldots \ldots \ldots \ldots \ldots \ldots \ldots \ldots \ldots \ldots . . . \ldots \ldots$ $30830^{\circ}-17-10$ 5
This rock weathers brown but on fresh fracture is almost white. The molecular ratio of lime and magnesia is nearly that of dolomite, but as the beds are not all of the same character the foregoing analysis does not represent accurately the composition of the whole formation.

In the narrow gorge just west of Hackberry Spring, in the southwestern part of the Ray quadrangle, the Messcal limestone stands almost vertical and has a thickness of 225 feet. In the section given above the total thickness is stated as 220 feet, exclusive of the vesicular basalt. This, however, is an estimate based on barometric readings corrected for a dip of about $25^{\circ}$. The average thickness of the formation as mapped in the Ray quadrangle and including the basalt flow may be taken as about 250 feet.

\section{TROY QUARTZITE.}

The Troy quartzite lies conformably above the Mescal limestone and below the Martin limestone. Prior to the detailed mapping of the Ray quadrangle this quartzite had not been recognized as a formation distinct from the lower or Dripping Spring quartzite, for in the Globe quadrangle there are no sections that show the two quartzites separated by the intervening Mescal limestones, and such brief papers on the geology of the Ray quadrangle as have appeared since the Globe report was published have dealt only with the immediate where the stratigraphic relations of the sedimentary rocks are less clearly displayed than elsewhere in the quadrangle. The name of the formation is derived from Troy Mountain, in the Dripping Spring Range.

The Troy quartzite is one of the most prominent and widely exposed formations in the Ray quadrangle. The beds differ greatly in thickness, ranging from thin flaggy or shaly layers to cross-bedded pebbly beds from 25 to 50 feet thick. On the whole the thicker beds are characteristic of the lower and middle portions of the formation. The upper part is invariably composed of thin, generally yellowish or rusty worm-marked shaly quartzite indicative of a change in sedimentation preparatory to the deposition of the Devonian limestone. The most characteristic material of these 
upper beds consists of layers, an inch or two thick, of fine-grained, unevenly colored brown, pink, and green quartzite separated by films of olive-gray shale whose cleavage surfaces are ridged and knotted with numerous worm casts. The quartzite layers appear almost dolomitic in color and texture, but the microscope shows them to consist chiefly of closely fitting quartz grains with specks of flocculent limonite and little nests of a green chloritic mica. The most noteworthy features of the thicker beds are their generally pebbly character, which is a useful means of distinguishing isolated exposures of the Troy quartzite from the pebble-free Dripping Spring quartzite, and their conspicuous cross-bedding. These characteristics are illustrated in Plate XXVII, $A$. While the Dripping Spring quartzite is nearly all arkosic the Troy quartzite shows little or no feldspar.

A not quite complete section of the Troy quartzite as exposed in nearly horizontal attitude $1 \frac{1}{2}$ miles southeast of Tam O'Shanter Peak, in the Dripping Spring Range, is given below, with approximate thicknesses.

\section{Section of Troy quartzite.}

11. Yellowish, rusty, thin-bedded quartzites with olive-gray shale partings roughened by worm casts; at least.........................

10. Fine-grained quartzite with very regular laminations from 2 to 6 inches thick.

9. Rather thin beds of white fine-pebbly quartzite

8. A single bed of massive cross-bedded finepebbly white quartzite, with layers of small quartz pebbles every few feet. Forms a cliff.................................

Sheet of porphyry, 25 feet.

7. Partly concealed; apparently rather thin bedded gray pebbly quartzite.................

6. Two beds of cross-bedded coarse quartzite or grit, with scattered pebbles of white quartz as much as 6 inches in diameter. Forms a

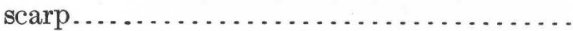

5. Conspicuously cross-bedded gray quartzite, with many layers of small quartz pebbles. No distinct separation into beds, but obscure laminations average about 1 foot in thickness. Forms a stepped slope. Microscope shows typical quartzite texture with enlarged interlocking quartz grains..........

4. Conglomerate with fairly well rounded pebbles, mostly of white quartz, as much as 4 inches in diameter, in an abundant crossbedded matrix of coarse quartzite..........

3. Soil-covered slope, apparently underlain by a yellowish shale or fine-grained quartzite.... Feet. 50
2. Cross-bedded pebbly quartzite in beds 4 to 10 feet thick. Pebbles quartz; rarely over 2 inches in diameter; in places scattered and in places concentrated in irregular lenticular layers. Weathers gray or rusty. Forms a stepped slope.....................

1. Bed of irregularly banded gray quartzitic breccia grading up into cross-bedded coarse grit or conglomerate with quartz pebbles. Breccia in lower part of bed contains angular fragments of white quartz 6 inches or less in diameter. Forms a cliff.

Bed No. 1 is the bottom of the Troy quartzite. Below it is the vesicular basalt at the top of the Mescal limestone.

Although much of the Troy quartzite is light gray or white on fresh fracture, the weathered exposures are generally buff, brown, rusty, or maroon. In the canyon northwest of Tam O'Shanter Peak, where the quartzite is finely exposed, the general tint is reddish brown, but the different parts of the formation vary in color from white or pale buff to dull dark red.

Determination of the exact thickness of the Troy quartzite is difficult, owing to the fact that few of the many fault blocks show a full section of the formation or give opportunity for detailed measurements. The section recorded above gives a total thickness of about $362 \frac{1}{2}$ feet but probably does not include all the upper beds. In the gorge west of Hackberry Spring a measurement across the edges of the nearly vertical beds gave 300 feet, but here also there are beds missing from the top of the formation. A little less than 2 miles northwest of Tam O'Shanter Peak the formation, here nearly horizontal, is exposed in full section between the Mescal dolomite and the Devionian limestone. The mapping here indicates a thickness of a little more than 350 feet. On Troy and Scott mountains the quartzite as mapped appears to be unduly thick, the distribution on Scott Mountain calling for a thickness of about 1,000 feet. This is clearly in excess of any possible real increase in the formation and probably is to be accounted for by faulting or flexing that is not distinctly shown at the surface. From all available information the average thickness of the formation is estimated to be about 400 feet. 


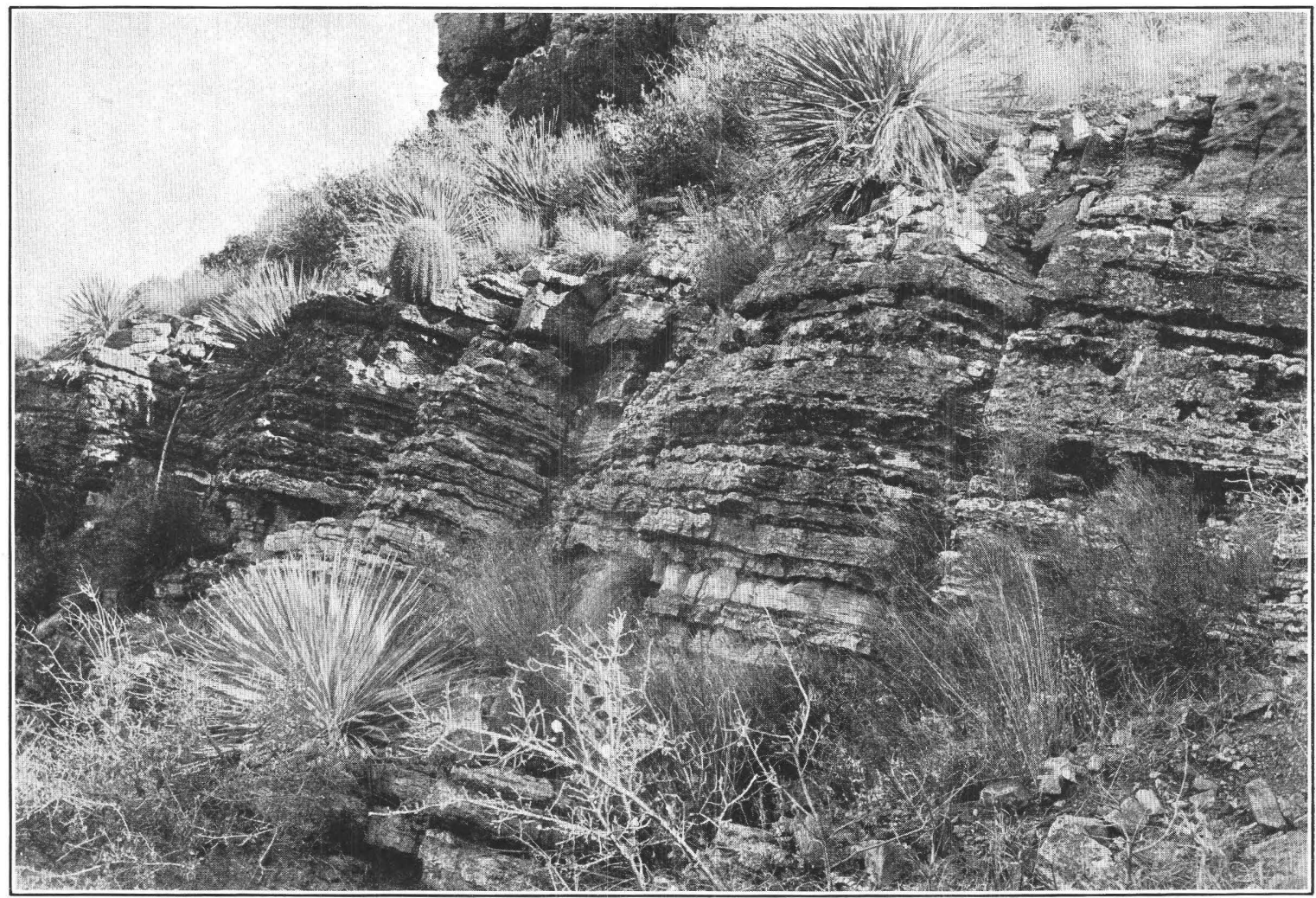

A. TYPICAL EXPOSURE OF THE CHERTY MESCAL LIMESTONE IN THE DRIPPING SPRING RANGE, 2 MILES SOUTH OF DRIPPING SPRING RANCH.

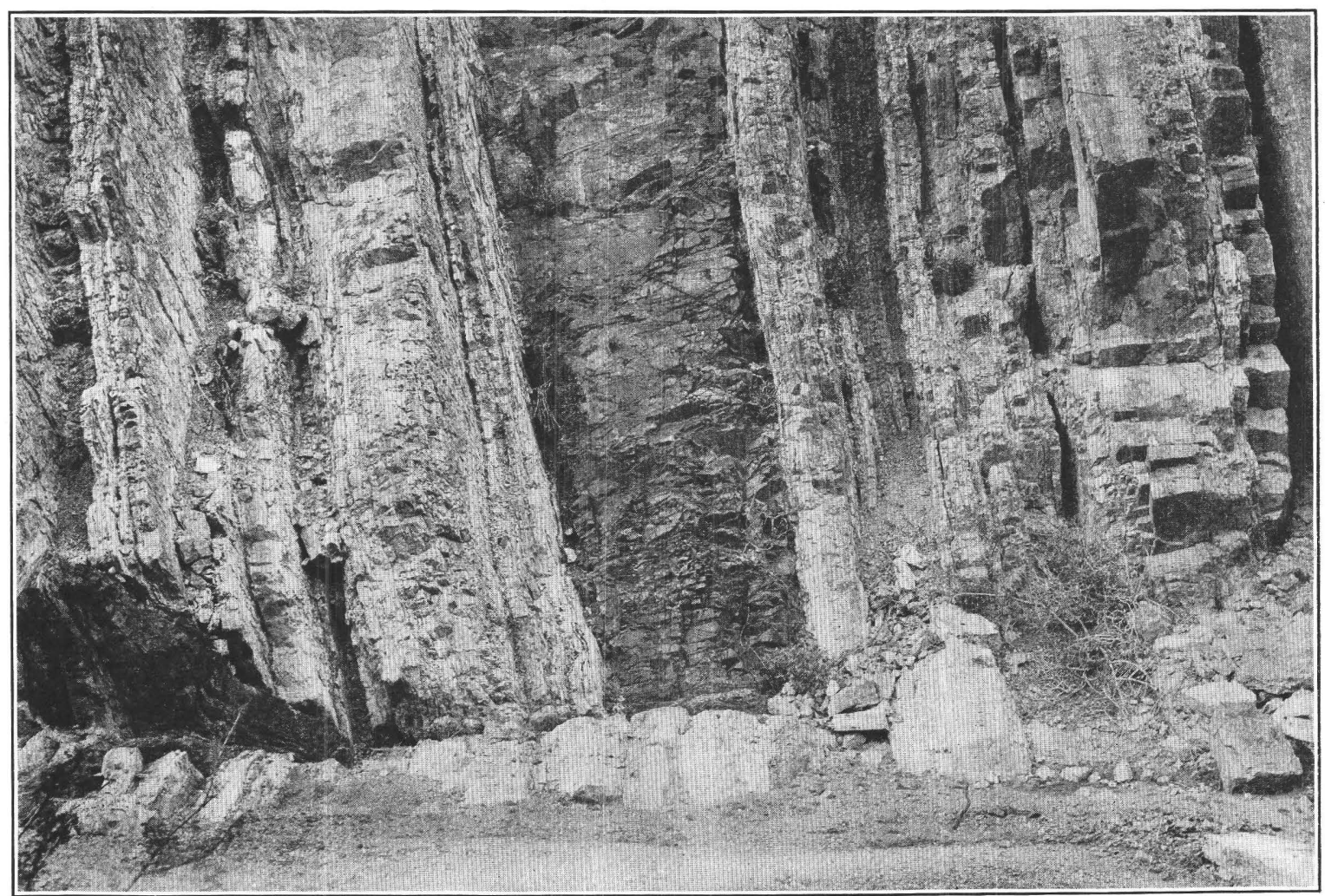

B. STEEPLY UPTURNED MESCAL LIMESTONE WITH INTRUSIVE DIABASE IN THE TORTILLA RANGE, ABOUT 6 MILES SOUTH OF KELVIN.

mescal Limestone in the Ray quadrangle, Ariz. 


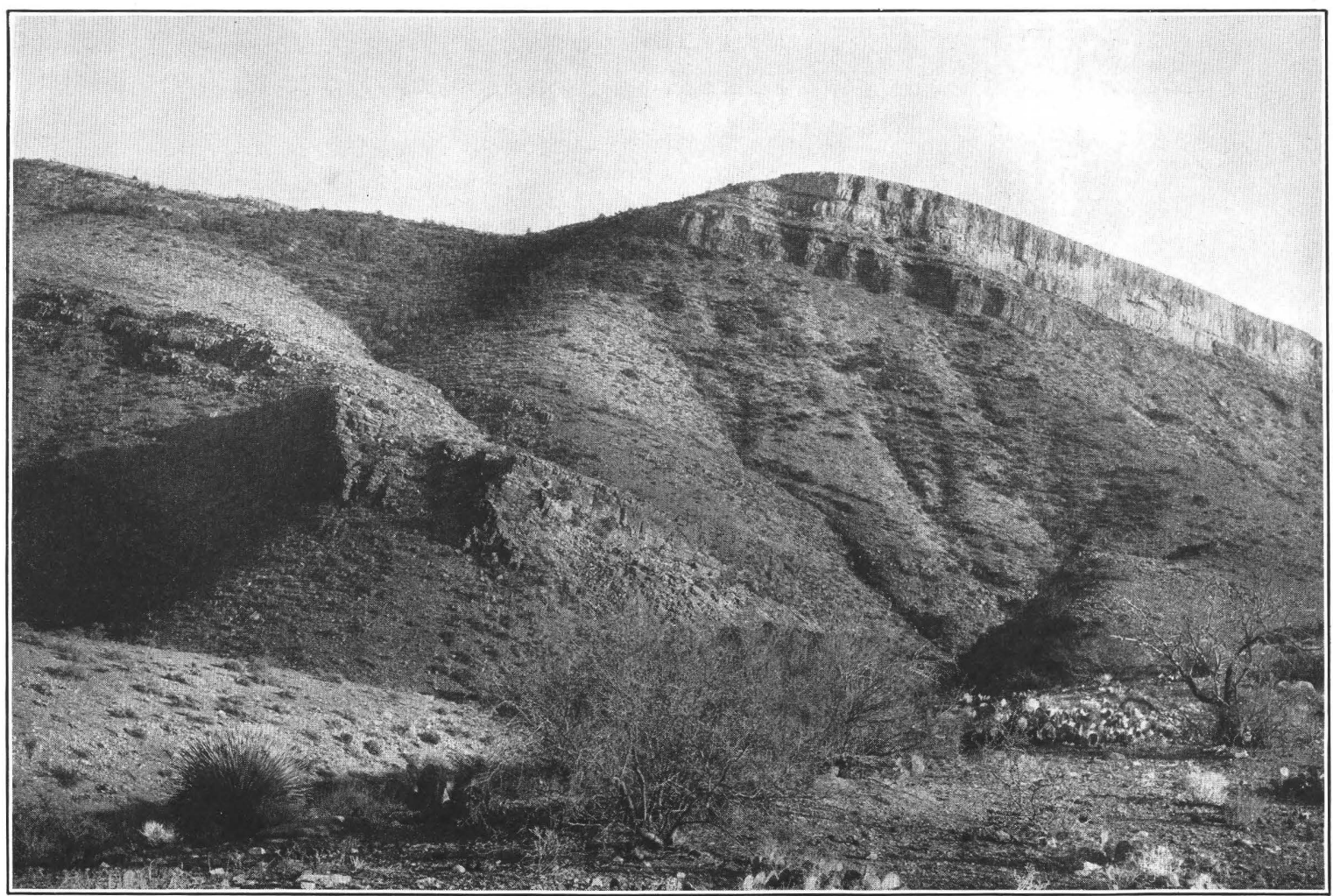

A. SECTION ON EL CAPITAN CREEK, MESCAL RANGE.

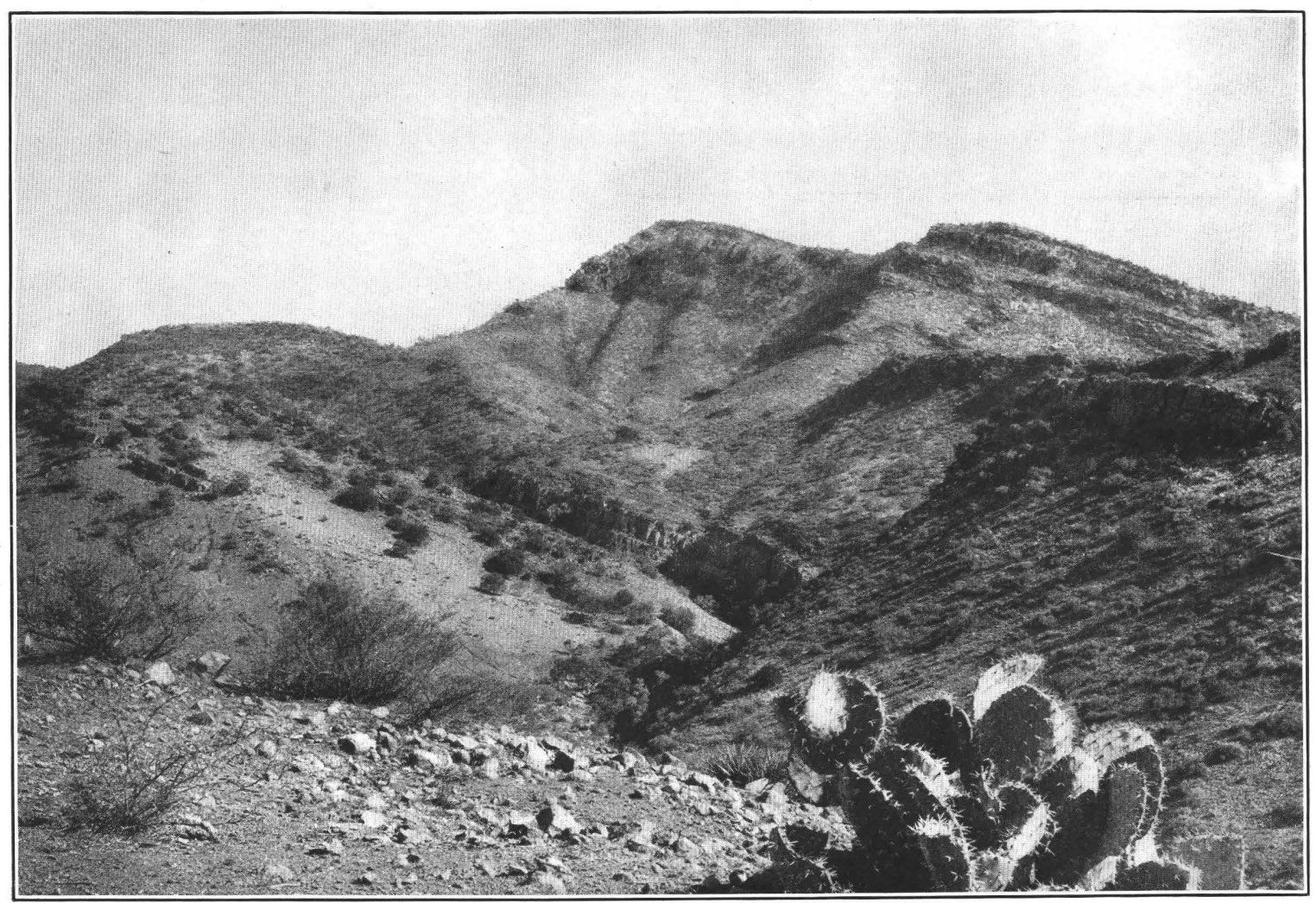

B. EL CAPITAN FROM THE NORTHWEST.

Sections of Paleozoic Rocks in the Ray Quadrangle, Ariz. 
The Troy quartzite, with its abundant pebbly layers and conspicuous cross-bedding, is suggestive of fluviatile or deltaic deposition. The upper part of this formation, however, grades into the undoubtedly marine Devonian beds.

\section{MARTIN LIMESTONE.}

The Martin limestone occupies conformably the stratigraphic interval between the underlying Troy quartzite and the overlying Tornado limestone and, with the possible exception of some of its unfossiliferous lower beds, is of Devonian age. The beds here separated as the Martin limestone were in the Globe quadrangle mapped with the overlying Carboniferous (Tornado) limestone under the name "Globe limestone."

As a whole the Martin limestone is a comparatively thin bedded formation, which weathers into slopes broken here and there by low scarps marking the outcrop of some bed a little harder or thicker than the rest. A typical natural section of the formation is shown in Plate XXIX, $A$. Distant views of such slopes show that the formation is divisible on the basis of color into two nearly equal parts. The prevailing hue of the lower division is light yellowish gray; the upper division, less uniform in tint, displays alternations of deeper yellow and darker gray. Detailed examination proves the lower division to consist mainly of very compact, hard, gray limestone in beds rarely more than 2 feet thick, with, at the base, a bed of impure yellow limestone containing abundant grains of quartz. This lowest bed, which in places is cross-bedded and contains so much detrital material that it might be classed as a calcareous grit, weathers to a rough sandy surface, but the overlying gray beds are characterized by solution surfaces that although uneven in general are smooth in detail. A characteristic feature of these compact lower limestones is the presence of little spherical, oval, or irregular concretions of dark chert, which as a rule are about the size of peas. No identifiable fossils have been found in this lower division of the Martin limestone, although it contains obscure traces of organic life.

About midway in the section is a bed, about 15 feet thick, of rusty-yellow impure sandy limestone showing flaggy lamination. Above this are dark-gray and yellowish limestones in beds of different thicknesses, with shaly partings. These strata are generally fossiliferous, some of the shaly partings particularly being orowded with Atrypa reticularis and other small Devonian brachiopods. Some very dark beds in this upper division of the formation are marked with an obscure mottling suggestive of the former presence of some of the corals which are abundant in certain beds of the Martin limestone at Bisbee but which in the Ray quadrangle have been less perfectly preserved. The top bed of the Devonian is a yellow calcareous shale which breaks up on exposure into minute thin flakes and which consequently has no prominent outcrops. The yellow color is characteristic of all natural exposures, although before weathering the shale is gray. Being overlain by the massive cliff-making Carboniferous limestone, the bed of shale is in many places concealed by talus, and its thickness was not exactly determined. It may be from 15 to 20 feet thick, but its base is not very clearly defined, for layers of similar shale ocour between some of the limestone beds in the upper part of the formation.

The Devonian limestone is generally magnesian and does not effervesce freely in cold dilute acid. An analysis of a typical specimen from the lower division of the formation is as follows:

Partial chemical analysis of Devonian limestone.

[R. C. Wells, analyst.]

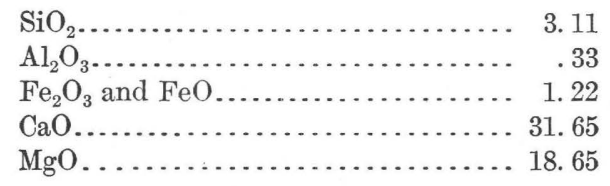

Measurements and estimates of the thickness of the Martin limestone in different parts of the quadrangle range from 300 to 350 feet. The average thiokness is considered to be 325 feet.

In contrast with the older formations, which have yielded no determinable organio remains, the upper division of the Martin limestone contains fossils at many horizons from the top of the rusty bed at its base to the lower layers of the yellow shale. In all 18 lots of fossils were collected and were referred to E. M. Kindle, 
then of the United States Geological Survey, who lists the following species:

Zaphrentis sp. undet.

Productella hallana.

Stropheodonta arcuata.

Stropheodonta demissa.

Stropheodonta varistriata.

Stropheodonta sp.

Leptostrophia cf. L. interstrialis.

Strophonella cf. S. ampla.

Schuchertella chemungensis.

Schizophoria striatula.

Atrypa reticularis.

Atrypa hystrix occidentalis.

Atrypa spinosa.

Camarotœchia sp.

Pugnax pugnus.

Spirifer orestes.

Spirifer hungerfordi.

Cyrtia cyrtiniformis.

Schizodus sp.

Paracyclas cf. P. elliptica.

Euomphalus cyclostomus?

Euomphalus sp.

Bellerophon sp. undet.

Dr. Kindle remarks with reference to this fauna :

On the ground of its close relationship to an Upper Devonian fauna of Iowa and its stratigraphic relations to the Carboniferous fauna of the Arizona section, I would place the fauna of the Martin limestone and its equivalent, the Devonian fauna of the Ray quadrangle, in the Upper Devonian. It is of course possible that the time range of this fauna in Arizona may include Middle as well as Upper Devonian, but that it includes the Upper Devonian in any event seems well established by the available evidence.

As the Devonian portion of the "Globe limestone" in the Globe quadrangle is continuous and identical with what is now designated the Martin limestone, fossils collected from it should be included in the Martin fauna. For convenience therefore the list of determinations made by H. S. Williams ${ }^{1}$ on the older collections, with slight changes by Dr. Kindle, to bring it into accord with present nomenclature, is given below.

Cf. sponge.

Cf. Rhodocrinus, crinoid stems and plates.

Atrypa reticularis Linné.

Productella hallana Walcott.

Stropheodonta calvini Miller.

Cyrtia cyrtiniformis (Hall and Whitfield).

Spirifer hungerfordi Hall.

Spirifer orestes Hall and Whitfield.

Spirifer whitneyi Hall.

Reticularia fimbriata (Conrad).

Cyrtina hamiltonensis Hall.

Martinia subumbona (Hall); cf. Spirifer infima Whidborne.

Pugnax pugnus (Martin).

Schuchertella chemungensis (Conrad) var.

Dielasma cf. D. calvini (Hall and Whitfield).

\footnotetext{
1 Ransome, F. L., U. S. Geol. Survey Prof. Paper 12, pp. 40-42, 1903.
}

TORNADO LIMESTONE.

The Tornado limestone, named from Tornado Peak, in the southeastern part of the Ray quadrangle, where it is extensively exposed, overlies with apparent conformity the Martin limestone and is equivalent to the Carboniferous portion of the "Globe limestone" as mapped in the Globe quadrangle. In places its upper limit is a surface of erosion upon which in general rests the Quaternary Gila conglomerate, although in the southeastern part of the Ray quadrangle there is an intervening andesitic formation, probably of Mesozoic age.

The Tornado limestone is generally light lead-gray in color and is divisible with respect to thickness and character of bedding into at least three members. The basal division, directly overlying the Devonian, is about 75 feet thick and forms the lower part of the scarp that is so prevalent a feature of the Carboniferous outcrops in central and southern Arizona. Under the action of erosion this division behaves as a single massive bed, but in reality it is made up of alternating dark and light gray layers, a foot or two thick which in cliff faces give this member a banded appearance, as may be seen in Plate XXIX, $A$ (p. 141). This banded division with a few transitional beds at its top is succeeded by a very massive member, fully 100 feet thick, within which, as exposed in cliff faces, there is as a rule little more than a suggestion of divisional bedding planes. This massive member (Pl. XXIX, $A$ ) is of lighter and more uniform tint than the basal member. The two together constitute the principal cliff-forming part of the Carboniferous limestone. The third division consists of beds generally thinner than those in the other two divisions but not separable from them by any marked lithologic distinction.

The Tornado limestone consists essentially of calcium carbonate and effervesces freely in dilute acid. An analysis of a typical sample is as follows:

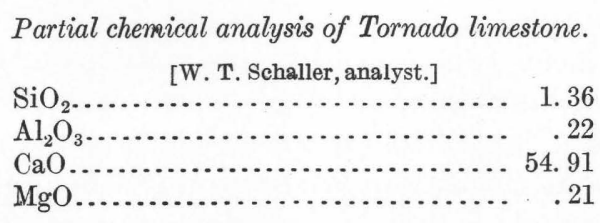

Thin layers of calcareous shale separate some of the beds, but these are a very subordinate part of the formation. 
Although nearly all the Carboniferous limestone contains fossil remains, there are few localities where full and satisfactory collections can be made. The beds of the two lower divisions carry abundant fragments of crinoid stems and less numerous rugose corals with long-winged spirifers and Rhipidomella. These appear in silicified form on weathered surfaces of the rock, but they can not readily be separated from their matrix. In the upper division appear different species of Productus and Spirifer, Derbya crassa, Composita subtitita, and Fusulina.

Of seven collections made at as many different localities in the Ray quadrangle, four, according to George H. Girty, of the Geological Survey, consist of Mississippian forms, and three of Pennsylvanian forms. His determinations of these fossils are as follows:

$$
\text { Mississippian fauna. }
$$

Syringopora aculeata Girty?

Menophyllum sp.

Amplexus? sp.

Rhipidomella aff. R. oweni Hall and Clarke.

Rhipidomella dubia Hall?

Leptæna analoga Phillips.

Schuchertella inflata White and Whitfield?

Chonetes sp.

Avonia arcuata Hall?

Camarotœchia metallica White.

Dielasma burlingtonense White.

Spirifer centronatus Winchell.

Brachythyris peculiaris Shumard.

Spiriferina solidirostris White.

Syringothyris sp.

Composita humilis Girty?

Cliothyridina sp.

\section{Pennsylvanian fauna.}

Fusulina sp.

Derbya crassa Meek and Hayden.

Productus semireticulatus Martin.

Productus cora D'Orbigny.

Pustula semipunctata Stevens.

Spirifer cameratus Morton.

Spirifer boonensis Swallow?

Composita subtilita Hall.

Myalina subquadrata Shumard.

According to Mr. Girty, the older of these two faunas is early Mississippian and the other is early Pennsylvanian. He notes that the conditions exhibited in the Ray quadrangle are apparently similar to those at Bisbee, where a limestone of probable early Pennsylvanian age (the Naco) rests directly on a limestone of early Mississippian age (the Escabrosa). The Mis- sissippian in the Ray quadrangle, therefore, corresponds to the Escabrosa limestone at Bisbee, and the Pennsylvanian limestone near Ray to the lower part of the Naco limestone.

In the Bisbee quadrangle the distinction between the Mississippian and Pennsylvanian limestones proved practicable, although the plane of demarcation is not definite. In the Ray quadrangle a similar distinction might possibly be made, but no satisfactory basis for it appeared in the course of the field work, and it is doubtful whether its accomplishment would be worth the additional labor involved. The cliff-making lower members of the Tornado limestone are certainly Mississippian, and probably a considerable part of the upper member also belongs to that epoch.

The original thickness of the Tornado limestone is unknown, for the formation was extensively eroded before the eruption of the andesitic lavas and before the deposition of the Gila conglomerate. In the vicinity of Tornado Peak and along the east flank of the Tortilla Range the limestone at present must be fully 1,000 feet thick, and it may at one time greatly have exceeded this thickness.

\section{NOMENCLATURE.}

The foregoing descriptions have been written with special reference to the formations as they are displayed in the Ray quadrangle, but they apply without essential change to the adjoining Globe quadrangle. When that area was studied, about 11 years ago, little was known of the stratigraphy of this part of Arizona and it appeared impracticable, in so intricately faulted a district, to map the sedimentary rocks in as great detail as has since proved possible in the Ray quiadrangle. In the Globe report the Scanlan conglomerate, Pioneer shale, Barnes conglomerate, and Dripping Spring quartzite, while distinguished in certain geologic sections, were mapped together as the "Apache group" and the Devonian and Carboniferous limestone were mapped as the "Globe limestone." As none of the numerous small fault blocks into which the Globe district is divided afforded a complete geologic section, and as no quartzite was found overlying limestone, all the quartzite was supposed to belong to one formation (the Dripping Spring quartzite), and all the limestone was supposed to belong to the Devonian and Carboniferous "Globe lime- 
stone." The "Globe limestone," as mapped, therefore included a little Mescal limestone, and the Troy quartzite was not distinguished from the Dripping Spring quartzite. Had the existence of the Mescal limestone and Troy quartzite been known when the Globe report was written, these two formations would probably have been included in the definition of the Apache group.

As at present constituted, this group consists of the following formations, named in ascending order: Scanlan conglomerate, Pioneer shale, Barnes conglomerate, Dripping Spring quartzite, Mescal limestone, and Troy quartzite. All are apparently conformable and are provisionally assigned to the Cambrian.

\section{SANTA CATALINA GEOLOGIC SECTION.}

As the Santa Catalina Range, northeast of Tucson, is being carefully studied by Prof. C. F. Tolman, jr., for the United States Geological Survey, and as my own observations were confined to an excursion of only six days' duration, under his guidance, the treatment accorded in this paper to the geology is necessarily brief and general.

The central feature of the range, as worked out by $\mathrm{Mr}$. Tolman, is a great post-Carboniferous intrusive mass oí siliceous muscovite granite modified to a gneissic rock near its margins, surrounded by a zone of intense contact metamorphism in which rocks of widely different kinds have been conspicuously affected. The oldest rock cut by this granite is a coarse, porphyritic biotite granite which, apparently as a result of the later granitic intrusion, grades into augen gneiss, and locaily this rock in turn has been transformed into a thinly fissile schist.

Resting upon a worn and weathered surface of the pre-Cambrian granite, as may be well seen on the east side of Oracle Ridge, north of Apache, is the Scanlan conglomerate, 10 to 12 feet thick, composed of imperfectly rounded pebbles of white quartz in a much silicified matrix. The conglomerate grades upward through several feet of very hard white quartzite into fine-grained sericite schists - the locally metamorphosed Pioneer shale. In some localities in the Santa Catalina Range the crystalline texture is so well developed that these altered shales might easily be mistaken for the preCambrian Pinal schist. It may be noted in this connection that the Pioneer shale has been metamorphosed to crystalline schist by the in- trusion of granodiorite at Troy, in the Ray quadrangle, also. The metamorphism there, however, is on a much smaller scale than in the Santa Catalina Range. Overlying the schist in the vicinity of Apache is the Barnes conglomerate, showing its well-rounded ellipsoidal pebbles. Its thickness here is about 12 feet. Although it is more silicified than the typical conglomerate of the Ray quadrangle, there can be little doubt of its stratigraphic identity. Southeast of Apache, on the east slope of the range, the Barnes conglomerate is overlain by a quartzite which is correlated with the Dripping Spring quartzite, although its character has been modified by the prevalent metamorphism. Stratigraphically above the quartzite is a formation that is probably the Mescal limestone. In a few places the limestone shows some of the cherty bands so characteristic of this formation near Ray, but as a rule the beds are much metamorphosed. Some have been squeezed and kneaded so that the chert layers have been drawn out into thin curly laminæ; others have been changed to crystal. line schist or to fine-grained garnet-epidote rock. The vesicular basalt that overlies the Mescal limestone in the Ray quadrangle was not recognized in the brief examination made of the Catalina Range.

Above the Mescal limestone is a pebbly quartzite with bands of conglomerate and with thin, shaly worm-marked beds near the top; in all probability this is the Troy quartzite.

The quartzite is overlain by generally rather thin bedded Devonian limestones, from which Mr. Tolman has collected fossils, followed in ascending stratigraphic succession by the thicker-bedded gray Carboniferous limestone. Finally, these formations are unconformably overlain by a thick series of red shales, containing some impure sandy limestone, with a heavy limestone conglomerate at the base. These beds may possibly belong to the Manzano group, ${ }^{1}$ but $\mathrm{Mr}$. Tolman has not yet found any fossils in them.

In the short time devoted to the Santa Catalina Range no attempt was made to measure the thicknesses of the different formations. Disturbance and metamorphism render this a difficult task, but Mr. Tolman will doubtless attempt it before the completion of his work. The general impression obtained, however, was

1 Lee, W. T., and Girty, G. H., The Manzano group of the Rio Grande valley, N Mex.: U. S. Geol. Survey Bull. 389, 1909. 


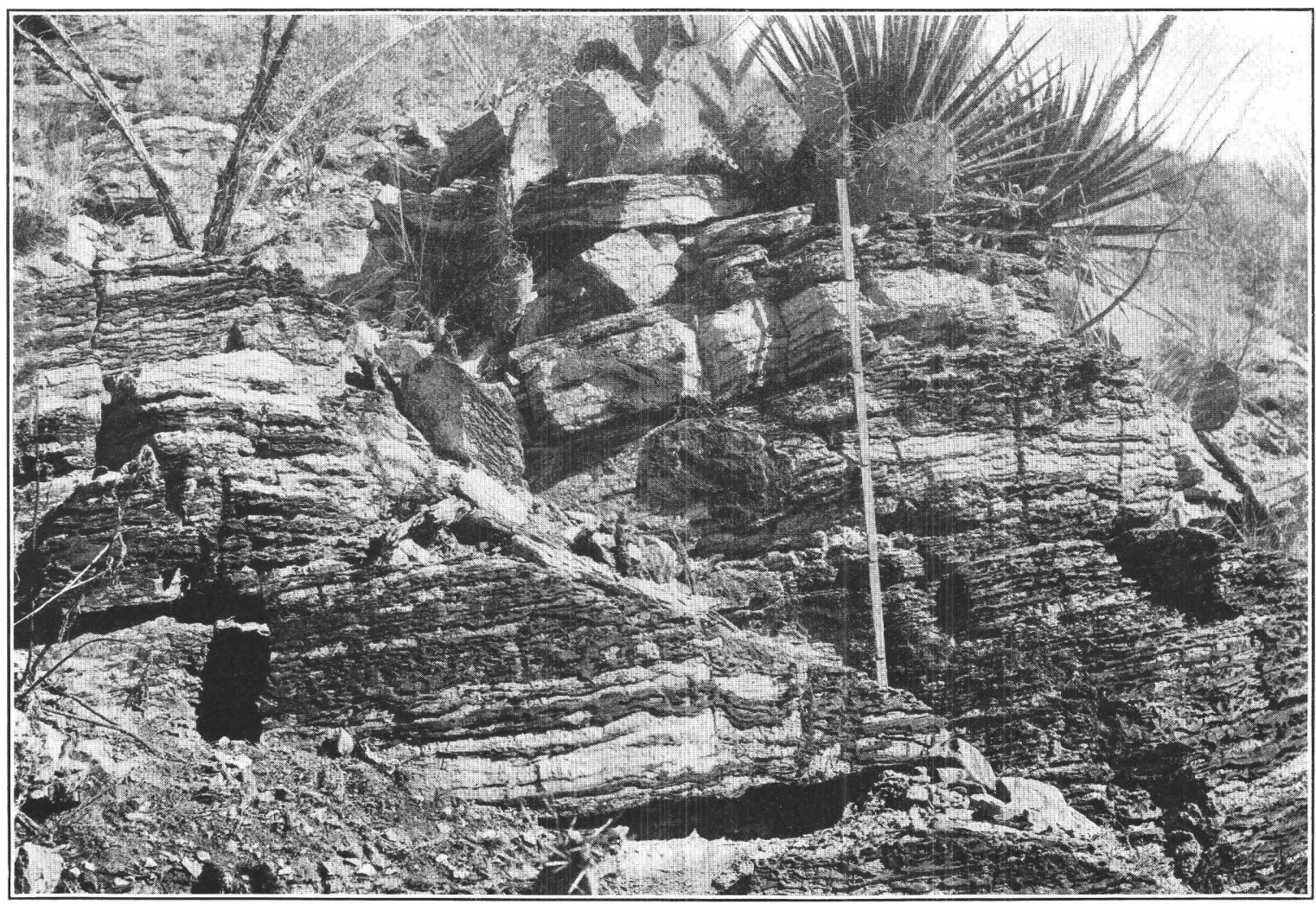

A. TYPICAL EXPOSURE THREE-FOURTHS OF A MILE NORTHWEST OF MILITARY HILL, TOMBSTONE DISTRICT.

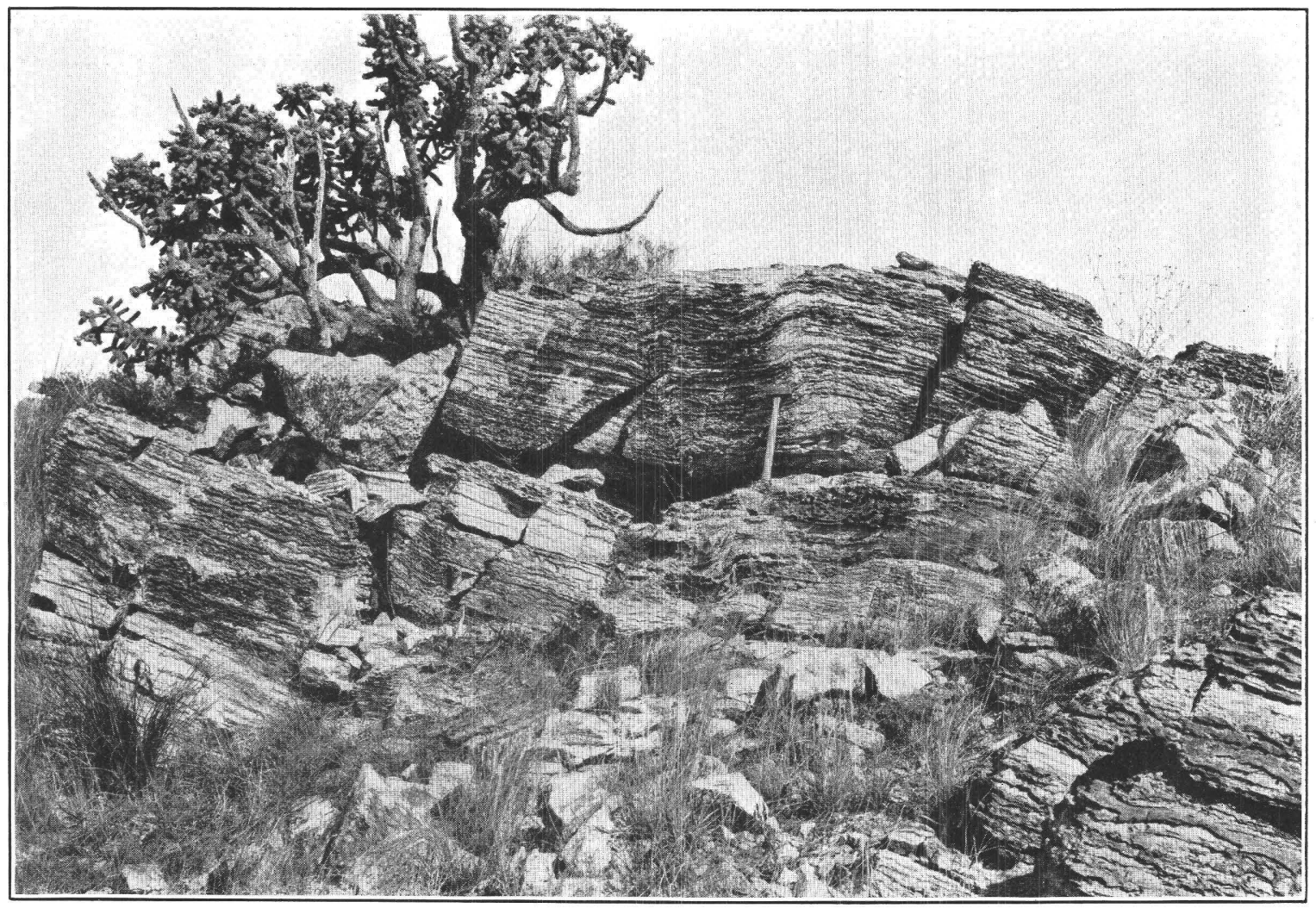

B. TYPICAL EXPOSURE ON ESCABROSA RIDGE, WEST OF BISBEE.

Abrigo Limestone in the Mule Mountains, Ariz. 
. 
that the formations making up the Santa Catalina section do not differ greatly in their respective thicknesses from those at Ray.

\section{BISBEE GEOLOGIC SECTION.}

From Apache, in the Santa Catalina Mountains, to Tombstone the distance is about 70 miles, and from Tombstone to Bisbee about 20 miles. Between the Santa Catalina Range and the north end of the Mule Mountains, where Tombstone is situated, lies a country about which little geologic information is available. The principal mountain range in this interval is the Whetstone, southwest of Benson. These mountains were visited over 10 years ago by Dumble, ${ }^{1}$ who reports over 1,300 feet of limestones and sandstones referable to the Carboniferous and 5,000 feet of sands and clays that he assigned to the Triassic. The range evidently is of much stratigraphic interest, especially in view of the fact that, as will presently be shown, the sections at Tombstone and Bisbee are considerably different from those of Ray and the Santa Catalina Range. Some carefully measured and described sections from the Whetstone Mountains would constitute a valuable contribution to the stratigraphy of Arizona, and as these mountains are readily accessible it is to be hoped that some geologist will before long find opportunity to study them.

A strictly geographic order of treatment would necessitate consideration of the section at Tombstone before that at Bisbee; but the latter was the first to be studied in detail and as it constitutes the type to which the Tombstone section conforms, it may conveniently be given priority of description here. ${ }^{2}$

Resting unconformably on the Pinal schist at Bisbee is the Bolsa quartzite, 430 feet thick, with a bed of conglomerate from 6 inches to a foot in thickness at its base. Most of the pebbles of this basal conglomerate are composed of white quartz and are less than 3 inches in diameter. The conglomerate is overlain, with no definite plane of division, by hard cross-bedded pebbly grits, the individual beds of which are from 10 to 20 feet thick, and above these lie thinner, finer-grained quartzites. The general color of the formation is rusty brown.

1 Dumble, E. T., Notes on the geology of southeastern Arizona: Am. Inst. Min. Eng. Trans., vol. 31, pp. 696-715, 1902.

2 For the original detailed descriptions of the formations at Bisbee see Ransome, F. L., The geology and ore deposits of the Bisbee quadrangle Ariz.: U. S. Geol. Survey Prof. Paper 21, pp. 28-56, 1904.
Conformably overlying the quartzite is the Abrigo limestone, 770 feet thick. This formation consists mainly of rather thin bedded limestones, in part sandy and dolomitic, with some shale. A laminated structure, due to the alternation of layers of gray limestone, generally 2 or 3 inches thick, with still thinner sheets of chert, is a conspicuous feature of the formation. These chert bands, as may be seen from Plate $\mathrm{XXX}, B$, are prominent on weathered surfaces, and the lithologic resemblance of the Abrigo to the Mescal limestone of the Ray quadrangle (see Pl. XXVIII, p. 140) is exceedingly close. The beds of the Abrigo are generally from 1 to 2 feet in thickness. Their prevailing color, as seen in large exposures, is dark greenish yellow.

In the typical Mount Martin section, near Bisbee, the Bolsa quartzite is immediately overlain by about 40 feet of thin-bedded, very cherty limestones, which break up on weathering into thin rusty plates. Above these are a few beds of gray limestone 2 feet in maximum thickness, alternating with fissile yellowish calcareous shales and with laminated cherty beds, such as have just been described. The upper 100 feet of the formation is made up of rather soft, sandy thin-bedded gray limestone, with one bed of harder gray limestone 6 feet thick about 40 feet from the top. The upper limit of the Abrigo formation is defined in the Mount Martin section by a bed of pure white quartzite about 8 feet in thickness. This quartzite is a persistent stratum and is found immediately underlying the Martin limestone, which carries Devonian fossils. Its thickness, however, is variable, and in places it grades downward into the upper sandy limestones of the Abrigo formation.

Analyses of two specimens of the Abrigo limestone are given below:

Partial chemical analyses of Abrigo limestone.

[W. F. Hillebrand, analyst.]

\begin{tabular}{|c|c|c|}
\hline & 1 & 2 \\
\hline 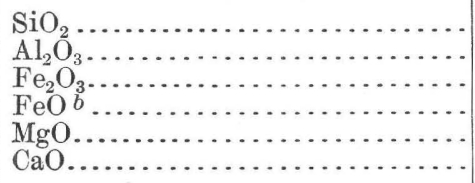 & $\begin{array}{r}11.80 \\
2.15 \\
1.08 \\
.48 \\
45.86\end{array}$ & $\begin{array}{r}12.53 \\
1.04 \\
1.26 \\
17.41 \\
27.28\end{array}$ \\
\hline
\end{tabular}


These analyses show that the different beds vary considerably in the ratio of lime to magnesia.

The oldest marine fossils in this region are found in the Abrigo formation and include trilobites, linguloid brachiopods, pteropods, and other early forms. The fossils collected from this formation were submitted to Dr. Charles D. Walcott, who reported that they are Middle Cambrian.

In the Mount Martin section the Martin limestone, carrying a Devonian fauna, overlies the Abrigo in apparent conformity. Its average thickness at Bisbee is about 325 feet. The beds most characteristic of the Martin formation are dark-gray hard, compact limestones which are generally well provided with fossils. Small brachiopods of rounded outline (Atrypa reticularis and Spirifer hungerfordi) are particularly abundant in some of the beds and give to the weathered surfaces of the limestone a nodular appearance which in the Bisbee quadrangle is peculiar to the Martin formation. A few of the beds are rich in corals, some of which weather out as distinct and in places well-silicified fossils, while others produce rather ill-defined white dendritic blotches in the dark limestone.

Associated with the preponderant dark limestones here and there are beds of lighter hue and some calcareous shales of a decided pinkish tint. These shales, which flake and crumble on exposure, are well exposed in the saddle just northeast of Mount Martin, where they carry abundant characteristic Devonian fossils. They occur also in several of the other areas of the Martin limestone, particularly on the southwest slopes of Escabrosa Ridge, but owing to their softness they are generally inconspicuous except where they are revealed by prospecting pits and tunnels. They belong in the lower half of the formation.

The upper limit of the Martin limestone is not everywhere sharply defined. In general it corresponds to the decided change from the dark compact limestones characteristic of this formation to the nearly white granular limestones, made up largely of crinoid stems, which characterize the Escabrosa formation. The actual plane of division, however, is rarely visible, owing to the tendency of the Escabrosa limestone to form cliffs and the consequent accumulation of talus over the contact. Even where no detritus conceals the relation of the two formations, there may be an intermediate zone 10 to 20 feet in thickness which contains no characteristic fossils and which it is impossible to assign with confidence, on purely lithologic grounds, either to the Martin or Escabrosa limestones.

The beds of the Martin limestone are usually less than 4 feet in thickness. They are thicker, on the whole, than those of the underlying Abrigo limestone, but thinner than those of the overlying Escabrosa limestone.

Chemically, the typical dark limestone of the Martin formation is a fairly pure calcium carbonate, containing a little silica but practically no magnesia.

The following species from the Martin limestone, collected in the course of the study of the Bisbee quadrangle in 1902, were identified by Prof. H. S. Williams:

Acervularia davidsoni (Milne-Edwards and Haime). Pachyphyllum woodmani (White). Cladopora prolifica (Hall and Whitfield). Stromatopora erratica (Hall).

Cyathophyllum cæspitosum (Goldfuss). Atrypa reticularis (Linné).

Cyrtia cyrtiniformis (Hall and Whitfield).

Dielasma calvini (Hall and Whitfield).

Schizophoria striatula (Schlotheim).

Productella speciosa Hall.

Delthyris consobrina (D'Orbigny).

Spirifer cf. S. jeremejevi (Tschernyschew).

Spirifer hungerfordi Hall.

Spirifer orestes Hall and Whitfield.

Spirifer cf. S. euryteines Owen (small specimen). Spirifer whitneyi Hall.

Stropheodonta demissa (Conrad).

Stropheodonta (fragilis) perplana (Hall).

Strophonella cælata Hall.

The following specimens were too imperfect for specific determination:
Coral, several species.
Crinoid stem.
Bryozoa.
Terebratula? (small).
Minute brachiopod (?).
Loxonema.
Platyceras.
Pleurotomaria.
Bellerophon.
Leperditia.

Mr. Williams concluded that the fauna of the Martin limestone is Meso-Devonian, although he regarded it as having close affinities with the Neo-Devonian fauna of New York. ${ }^{1}$ 
Overlying the Martin limestone at Bisbee is the Escabrosa limestone, made up generally of rather thick-bedded, nearly white to dark gray granular limestones, which on close examination are seen to be made up very largely of fragments of crinoid stems. . Near the base the individual beds are commonly 10 or 15 feet in thickness, but above the first 100 feet thicknesses of 1 to 5 feet are the rule, though there are a few more massive beds. The formation as a whole is a pure nonmagnesian limestone, containing practically no arenaceous sediments and only scattered irregular bunches and nodules of chert, usually in its upper part.

Fossils occur at many horizons from the bottom to the top of the formation, but, with the exception of small scattered corals and the abundant fragments of crinoid stems, they are rarely conspicuous and as a rule do not appear on weathered surfaces of the limestone. The general appearance of the Escabrosa formation is white or light gray, but some dark-gray beds occur, particularly near the top.

The fossils collected from the Escabrosa limestone were submitted to George H. Girty, who reported ${ }^{1}$ that they probably represent the earlier half of Mississippian time, including the Kinderhook and Osage divisions. The following are some of the characteristic species listed by him, with his comment:

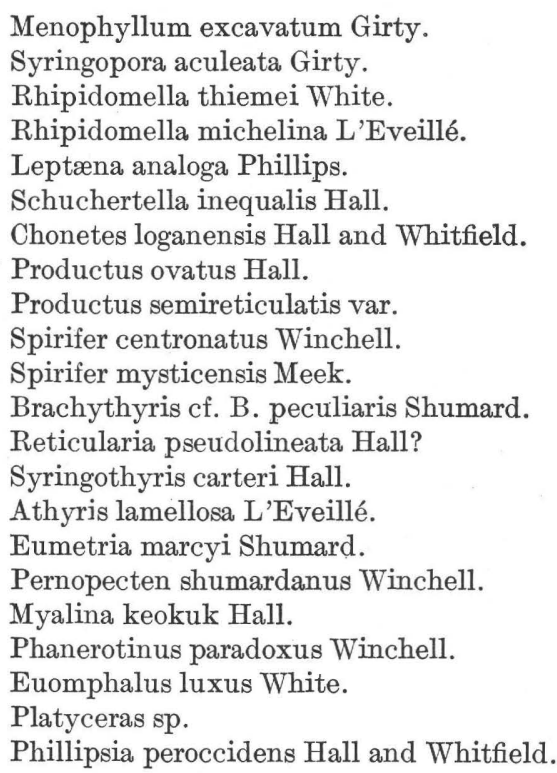

Associated with some of the species in the above list were found others which probably indicate a slightly higher horizon than the Osage-in other words, one in the Mera-

1 Ransome, F. L., U. S. Geol. Survey Prof. Paper 21, pp. 46-54, 1904. mec group. There are such forms as Lithostrotion sp., Meekopora sp., Archimedes sp., Pustula cf. P. biseriata, and Spirifer cf. $S$. tenuicostata. On the other hand, no fossils of a well-marked Chester type have been found, so that so far as the evidence at hand is concerned the upper Mississippian is missing. It is also true that many of the striking Osage forms have not been found-for example, Schizophoria swallowi, Orthotetes keokuk, Spirifer grimesi, and Spirifer logani-nor the wealth of crinoids which characterize this horizon in certain areas in the Mississippi Valley. I am disposed to regard the absence of these Osage forms as due to local conditions but also to believe that upper Mississippian time is really in large part unrepresented.

Measurements of the thicknesses of the Escabrosa limestone in different parts of the Bisbee quadrangle varied from 600 to 800 feet, the upper limit of the formation being difficult to determine with precision. The average thickness is taken as 700 feet.

The Naco limestone, which overlies the Escabrosa conformably and with no distinct lithologic change, is made up chiefly of light-colored beds, which consist essentially of calcium carbonate. The beds range in thickness from a few inches to 10 feet but are usually thinner than those of the Escabrosa limestone. They differ from the latter also in texture, the typical Naco limestone being compact and nearly aphanitic, ringing under the hammer, and breaking with a splintery fracture, whereas the Escabrosa limestone is usually more granular and crystalline and crumbles more readily when struck. There are, however, exceptions to this rule, dense aphanitic beds occurring here and there in the Escabrosa formation and granular crinoidal beds being not uncommon in the Naco limestone.

Fossils, particularly brachiopods, are much more abundant in the Naco than in the Escabrosa limestone, and in some places they make up a considerable part of individual beds and weather out conspicuously upon exposed surfaces.

While the greater part of the 3,000 feet or more of the Naco formation is made up of fairly pure gray limestone, certain thin beds of a faint-pink tint occur at different horizons and are often a useful means of distinguishing the Naco from the Escabrosa limestone. These pink rocks, which weathering usually shows to have an inherent lamellar or shaly structure, are very fine grained and compact in texture. They effervesce freely with cold dilute acid and are evidently composed chiefly 
of calcium carbonate. Examination of natural surfaces with a lens, however, shows the presence of minute quartz grains and tiny flakes of mica. Chert is not uncommon in the Naco formation; it occurs as irregular bunches and nodules in beds of otherwise pure limestone or as the result of the silicification of thin fossiliferous beds throughout their thickness. It is also particularly abundant along and near zones of fissuring and faulting.

According to Mr. Girty the fossils from the Naco limestone belong to two groups, one representing early and the other later Pennsylvanian time. The earlier fauna include the following:

Fusulina cylindrica Fischer de Waldheim.

Chætetes milleporaceus Milne-EJwards and Haime.

Derbya crassa Meek and Hayden.

Productus semireticulatus Martin.

Productus cora D'Orbigny.

Productus coloradoensis Girty.

Pustula nebraskensis Owen.

Postula semipunctata Shepard.

Marginifera wabashensis Norwood and Pratten.

Spirifer rockymontanus Macou.

Spirifer cameratus Morton.

Squamularia perplexa McChesney.

Spiriferina kentuckyensis Shumard.

Composita subtilita Hall.

Hustedia mormoni Marcou.

Dielasma bovidens Morton.

Phillipsia major Shumard.

The later fauna contains many species not yet described. The following forms have been discriminated:

Fusulina cylindrica Fischer de Waldheim.

Michelinia? sp.

Lophophyllum cf. L. profundum Milne-Edwards and Haime.

Echinocrinus, several sp.

Productus, semireticulatus type.

Postula cf. P. norwoodi Swallow.

Marginifera cf. M. wabashensis Norwood and Pratten.

Martinia sp.

Composita subtilita Hall.

Plagioglypta cf. P. canna White.

Worthenia sp.

Murchisonia?, several sp.

Euomphalus sp.

Omphalotrochus, several sp.

Cyclonema sp.

Orthonema sp.

Sphærodoma sp.

Bellerophon cf. B. crassus Meek and Worthen.

Euphemus sp.

This fauna, according to Mr. Girty, is closely related to that of the limestones of the Hueco Mountains, in western Texas.
From the preceding descriptions it appears that Paleozoic time is represented in the Bisbee quadrangle by beds having a total thickness of a little over 5,000 feet. Of these the lower beds, 430 feet thick, are quartzites and the remaining 4,570 feet of beds are so predominantly calcareous that they may be collectively designated limestones. The Pennsylvanian series is represented by at least 3,000 feet of strata (the Naco limestone), but only 340 feet (the Martin limestone) can be assigned to the Devonian, and the Silurian and Ordovician appear to be wholly without stratigraphic representation.

\section{TOMBSTONE GEOLOGIC SECTION.}

The Paleozoic section at Tombstone closely resembles that at Bisbee. The Bolsa quartzite has about the same thickness and character. The Abrigo limestone is 70 feet thinner than at Bisbee, and the bed of quartzite at its top also appears to be a little thinner than it is in the region to the south. The Martin limestone has a larger proportion of shale at Tombstone than at Bisbee, but contains similar coralbearing beds and the fauna, according to Dr. E. M. Kindle, is the same as that of the Martin limestone at the type locality. The beds at Tombstone maintain the same total thickness, 340 feet, as at Bisbee.

The Mississippian division of the Carboniferous is approximately 500 feet thick at Tombstone, as against 700 feet at Bisbee, but owing to the lack of any plane of lithologic distinction between the Mississippian and the Pennsylvanian in this region these figures are not very reliable.

The Pennsylvanian (Naco) is well represented at Tombstone and consists almost exclusively of limestone. Of the fossils collected from the Naco limestone in the Tombstone district George H. Girty writes:

The Pennsylvanian lots exhibit two faunal types which I understand occupy relatively higher and lower positions in the section. In the most characteristic lot of the upper horizon I recognized the following species:

Echinocrinus sp.

Productus ivesi Newberry.

Composita subtilita Hall.

Deltopecten vanvleeti Beede.

Pleurotomaria? sp.

Bellerophon aff. B. stevensianus McChesney.

Euphemus sp.

Omphalotrochus obtusispira? Shumard.

Trochus? sp.

Orthonema socorroense Girty. 


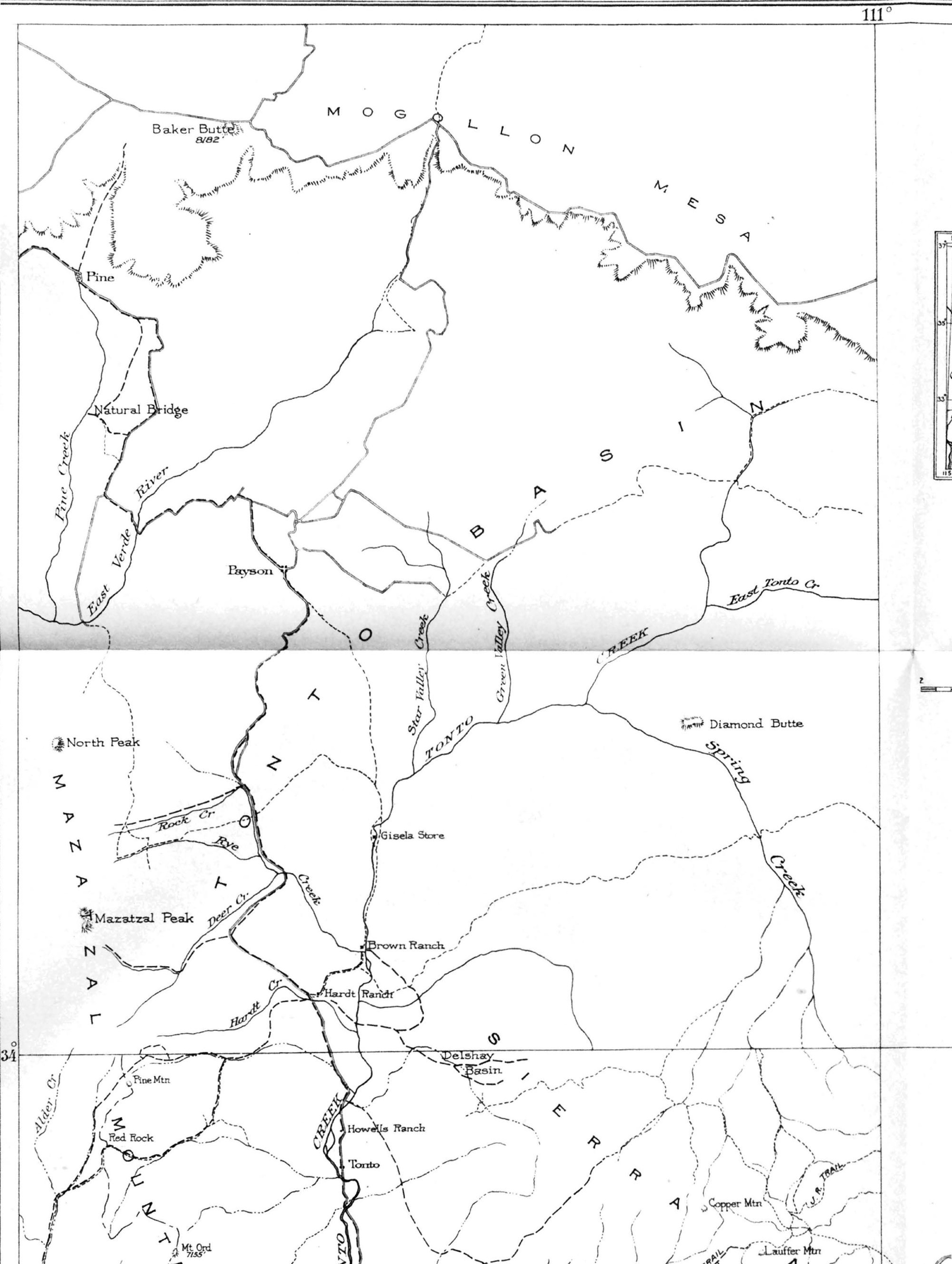


The other lots add several species to this fauna, especially one or two large species of Schizostoma, a large Bellerophon, possibly $B$. majusculus, and a Murchisonia resembling $M$. terebra.

These two Pennsylvanian faunas bear a close relationship to the faunas of the Magdalena limestone and Manzano group of New Mexico, and it seems highly probable that the upper Naco limestone will correlate with the Manzano and the lower Naco with the Magdalena.

The fauna of the upper Naco is also related to a fauna found in the middle or upper part of the Hueco limestone. The lower Hueco fauna, while resembling in some respects that of the lower Naco, contains a good many species not yet found in the latter, and I am unable to state whether we have merely the same fauna with regional modifications or two faunas, one of which is older than the other. I rather incline to the former belief.

The thickness of the Naco formation at Tombstone has not been measured, but probably amounts to several hundred feet. The limestone was extensively eroded before the deposition of the Mesozoic beds that unconformably overlie it in part.

\section{CLIFTON GEOLOGIC SECTION.}

At Clifton, 90 miles east-southeast of Globe, ${ }^{1}$ about 1,500 feet of apparently conformable Paleozoic beds rest unconformably on Pinal schist and coarse red granite. At the bottom of the stratigraphic column is the Coronado quartzite, 200 feet thick, with a layer of conglomerate at its base as much as 50 feet thick. A section of the quartzite southwest of Morenci is described by Lindgren ${ }^{2}$ as follows:

\section{Section of Coronado quartzite.}

White quartzitic sandstone................ 50 Banded pink and maroon quartzitic sandstone, form-

ing precipitous bluff...................... 162

Quartzitic conglomerate................... 10

Sandstone................................. 3

Quartzitic conglomerate (pebbles 1 inch in diameter). 8

Coarse sandstone (base) $\ldots \ldots \ldots \ldots \ldots \ldots \ldots \ldots \ldots, 10$

Above the Coronado quartzite lies the Longfellow limestone, 200 to 400 feet thick, which consists of cherty limestone in the upper part grading downward into shaly beds near the base. One of the sections given is as follows:

1 Lindgren, Waldemar, The copper deposits of the Clifton-Morenci district, Ariz.: U. S. Geol. Survey Prof. Paper 43, 1905. See also U. S. Geol Survey Geol. Atlas, Clifton folio (No. 129), 1905.

2 Op. cit. (Prof. Paper 43), p. 60.
Section of Longfellow limestone one-fourth mile south of Modoc Peak.

Feet.

Buff limestone............................... 15

Quartzitic sandstone....................... 10

Bluff of brownish-gray cherty limestone............ 140

Shaly limestone........................... 90

Coarse gray sandstone....................... 10

Sandy and shaly limestone (base) . . . . . . . . 115

380

Fossils are scarce in the Longfellow limestone. In the lower shaly part were found a few small lingulas and other forms that, while insufficient for a certain determination of age, were regarded by Dr. C. D. Walcott as indicating probably the uppermost part of the Cambrian. Near the top of the formation were found gastropods and fragments of trilobites which E. O. Ulrich determined as early Ordovician. ${ }^{1}$ Lindgren places the Coronado quartzite in the Cambrian and the Longfellow limestone in the Ordovician. ${ }^{2}$

Resting upon the Longfellow limestone is the Morenci shale, consisting of a lower division of compact argillaceous limestone 75 feet thick and an upper division of dark clay shale about 100 feet thick. A few fossils were found in the lower division and were referred provisionally by Prof. H. S. Williams to the Devonian. ${ }^{3}$

Overlying the Morenci formation is the Modoc limestone, 180 feet thick, of Mississippian age. ${ }^{4}$ North of the exposures of the Modoc limestone and not in contact with it is a limestone formation 500 feet thick which Lindgren has called the Tule Spring limestone. It carries both Mississippian and Pennsylvanian fossils, and the lower 200 feet of the formation is regarded by Lindgren as in a general way equivalent to the Modoc limestone. The Tule Spring limestone is limited above by the pre-Cretaceous unconformity.

\section{ROOSEVELT GEOLOGIC SECTION.}

The gorge through which Salt River, after passing the Roosevelt dam, traverses the south end of the Mazatzal Range (see Pl. XXXI), affords an excellent section of the beds from the Mississippian down to the granite. This

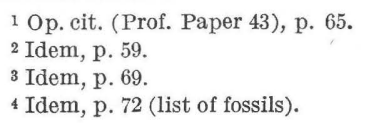


exposure has been very briefly noted by Lee, ${ }^{1}$ whose diagrammatic section of the beds is reproduced here as figure 11. The explanatory lettering that evidently was intended to accompany the diagram was inadvertently omitted from Mr. Lee's paper, but the bed marked 1 is obviously Quaternary material, 2 is intended for Carboniferous limestone, 3 is the Troy quartzite, 4 is the Mescal limestone, 5 is the Dripping Spring quartzite with the Barnes conglomerate at its base, 6 and 9 correspond to the Pioneer formation, and 10 is the Scanlan conglomerate. The numerals 7 and 8 designate a thick sill of diabase in which the thin layer (shale?) is probably not so persistent as is indicated, and 11 is coarse pre-Cambrian granite. Lee ${ }^{2}$ cites a personal communica-
Its dip is $35^{\circ} \mathrm{NE}$. The pebbles, unlike those in the typical Scanlan conglomerate of the Ray section, are well rounded and are as much as 9 inches in diameter. They are composed of white quartz, brown fine-grained vitreous quartzite, and a little red jasper. They lie close together in a matrix of dull red-brown coarse sandstone. On the whole, the conglomerate locally resembles the typical Barnes conglomerate of the Ray quadrangle more than it does the Scanlan conglomerate of the same area, of which, however, it is undoubtedly the stratigraphic equivalent.

The Scanlan conglomerate is conformably overlain by rather coarse brown cross-bedded arkosic sandstone, flecked with small light spots, like those in the typical Pioneer shale,

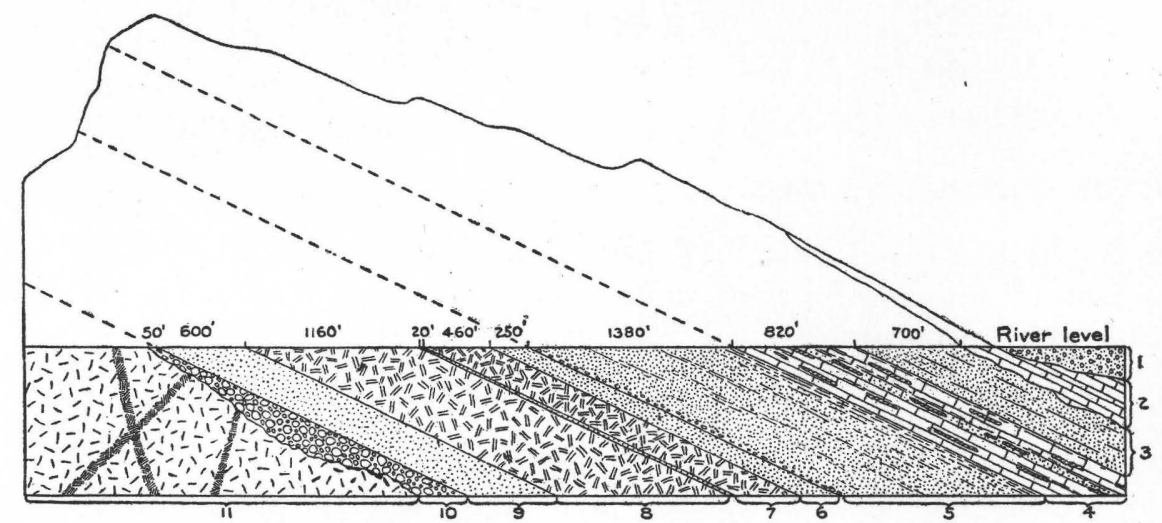

FIGURE 11.-Section through Salt River gorge near Roosevelt, Ariz., looking northwest. (After W. T. Lee.) See text for explanation.

tion from Dr. C. D. Walcott to the effect that "the Carboniferous limestones rest directly and unconformably upon the quartzites and argillites of the Algonkian" and agrees that all the beds below the supposed unconformity (which he did not himself see $^{3}$ ) are Algonkian.

The base of the sedimentary series is exposed about half a mile downstream from the dam, where the Scanlan conglomerate, here 30 feet thick, rests on an erosion surface of coarse red granite. This color is the result of pre-Cambrian weathering, and is characteristic of this old surface throughout central Arizona. The red tint generally fades to gray a short distance from the contact. The surface shows gentle undulations, and the conglomerate is probably variable in thickness.

1 Lee, W. T., Underground waters of Salt River valley, Ariz.: U. S. Geol. Survey Water-Supply Paper 136, pp. 96-98, 1905.

2 Idem, p. 96.

3 Oral communication. and containing a few small pebbles. The lowest three beds of this sandstone are each about 10 feet thick and are separated by partings of maroon shale. Above them both the sandstone beds and the layers of shale become thicker for about 140 feet, to the base of a great diabase sill, probably 700 to 800 feet thick. Despite the size of this intrusion the shales above and below it show no metamorphism other than slight baking and hardening. Above the diabase lies about 100 feet of typical spotted maroon Pioneer shale.

The shale is overlain by the Barnes. conglomerate. The pebbles are smaller than those in the typical conglomerate of the Globe-Ray region, most of them being less than 4 inches in diameter, and there is a rather large proportion of sandy matrix. As exposed in the cliffs, high above the river, the Barnes conglomerate appears to be rather better developed 
than in the roadside exposure studied, where its thickness is from 15 to 20 feet.

Overlying the Barnes conglomerate is the Dripping Spring quartzite, which has an estimated thickness of 500 to 600 feet. For about 140 feet above its base the banded reddishbrown quartzite is separated rather indistinctly by thin partings of dark-red shale into beds 10 feet or less in thickness. Above this zone the beds are thinner and show some faint crossbedding. The upper 180 feet of the formation consists of thinly laminated striped dull-red and black quartzite, which as a rule forms a cliff. The cliff dwellings of the Tonto National Monument, about 4 miles southeast of the dam, are in these upper beds. So far as seen the Dripping Spring quartzite at Roosevelt, as well as near Ray, is free from pebbles.

On top of the Dripping Spring quartzite is the Mescal limestone, which is very well exposed at Roosevelt, especially along the Phoenix road from the dam to a point about 100 yards beyond the first sharp turn to the east. The beds dip $25^{\circ} \mathrm{NE}$., and the plane of contact between the Dripping Spring quartzite and the Mescal limestone, if projected across the gorge, would intersect the dam about halfway between the top and the bottom.

The Mescal near the Roosevelt dam consists of hard dolomitic cherty limestone in beds that are for the most part less than 2 feet thick, with little or no shaly material. The roughly parallel but wavy and irregular layers of chert so characteristic of the formation farther south are equally conspicuous near Roosevelt in weathered exposures transverse to the bedding planes. The general color of the formation is darker than at Ray, and the chert bands near the base are black and flinty. On fresh fractures the Mescal limestone is gray, pink, or yellow. The local thickness of the formation is about 300 feet. Overlying the limestone, as at Ray, is a flow of rusty basalt, from 40 to 60 feet thick, as exposed near the east end of the dam, and vesicular both at top and bottom.

Overlying the basalt flow is the local equivalent of the Troy quartzite, which here may be more appropriately called the Troy sandstone. As exposed along the road between the dam and the cement quarry, this formation is made up as follows:
Section of Troy sandstone.

Feet.

3. Cross-bedded pebbly sandstone. Lower beds massive and weathering dark reddish brown. Lower massive bed near dam beautifully striped in red and gray. Upper beds thinner, mostly under 2 feet, with calcareous cement.............. 100

2. Cross-bedded pebbly sandstone, with layers of brown, micaceous sandy shale............. 40

1. Dark-brown shale grading upward by interbedding into sandstone.......................... 20 Base.

The Troy sandstone at Roosevelt is much thinner, therefore, than in the Ray-Globe region.

Overlying the Troy with no conspicuous difference in general appearance is a series of generally rather thin-bedded limestones and sandstones or quartzites. The lower beds are very compact gray limestones, which are succeeded by impure sandy limestones interbedded with calcareous sandstones and some quartzite. The topmost bed is shale which weathers to thin yellow flakes and is considered to be lithologically and stratigraphically identical with the yellow shale that is believed to mark the top of the Devonian in the Ray-Globe region. The formation as a whole is more sandy than the Martin limestone of the Ray quadrangle and is less fossiliferous. A few fossils were collected in 1912 from the top of the sharp hill just east of the dam and south of the cement quarry, but Dr. Kindle found that only one species, probably Schizophoria striatula (Schlotheim), is represented. He writes, in a personal letter:

Before offering a final opinion as to the age of the fauna represented by this shell I would like to see another collection, including other species. I am inclined provisionally to refer the beds represented by this single species to the Devonian.

The locality was again visited in 1914 and additional fossils were collected. Edwin Kirk, of the United States Geological Survey, to whom they were submitted, lists them as follows:

Cladopora sp.

Schizophoria stratula var. australis Kindle.

Schuchertella sp.

Camarotœchia contracta Hall (?).

Camarotœchia sp.

Spirifer whitneyi var. animasensis (Girty).

Modiomorpha sp. 
Mr. Kirk remarks that this fauna can be correlated with that of the Martin limestone of Bisbee and that of the Ouray limestone of Colorado. He states that there can be no doubt, of the Devonian age of the material.

No measurement of the Devonian near Roosevelt was made, but the thickness is estimated roughly at 300 feet.

Overlying the yellow shale at the top of the Devonian beds is the light-gray pure and comparatively massive Carboniferous limestone. This is the rock that was quarried for cement during the construction of the dam. It forms the little knoll northwest of the dam on which stands the hotel. Fossils were collected by W. T. Lee from the limestone near Roosevelt and from Windy Hill, about 5 miles east of the dam. G. H. Girty, ${ }^{1}$ to whom they were referred, identified the fauna as early Mississippian and lists the following forms:

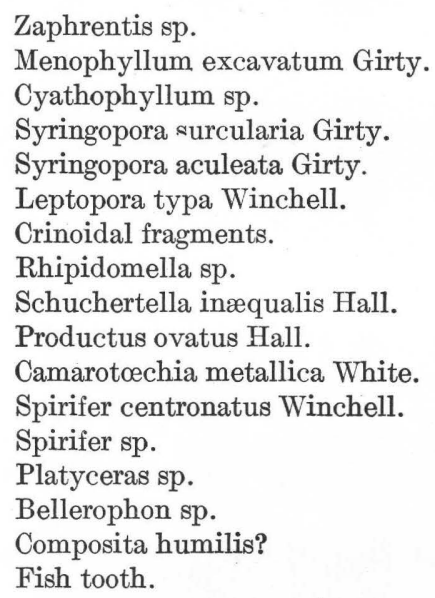

It appears from the foregoing description that the stratigraphic column at Roosevelt is composed of the same formational units as that of the Globe-Ray region and that the Mississippian limestone lies conformably on the Devonian.

\section{CANYON CREEK GEOLOGIC SECTION.}

The region adjacent to Fort Apache, northeast of Roosevelt, received some attention from the geologists of the Wheeler Survey ${ }^{2}$ and was later described by Reagan. ${ }^{3}$ Marvine at least, in his trip from Fort Apache to the Gila Valley, undoubtedly saw the two quartz-

\footnotetext{
1 Lee, W. T., Underground waters of Salt River valley, Ariz.: U. S. Geol. Survey Water-Supply Paper 136, pp. 97-98, 1905.

2 Gilbert, G. K., U. S. Geol. Surveys W. 100th Mer. Rept., vol. 3, pp. 163-165, 1875. Marvine, A. R., idem, pp. 215-225.

3 Reagan, A. B., Geology of the Fort Apache region in Arizona: Am. Geologist, vol. 32, pp. 265-308, 1903.
}

ites that have since been called the Dripping Spring and Troy quartzites, but he refers all exposures of both to the "Tonto sandstone." Gilbert also applies the same name to all the arenaceous rocks below the Redwall limestone, but it is possible that he had only distant views of the Dripping Spring quartzite, which apparently does not appear in the plateau escarpment. Reagan describes a number of stratigraphic sections and notes certain sediments as being unconformable under the "Tonto sandstone" and therefore of Algonkian age. These older rocks probably include the Pioneer shale, but how much more is not clear from his descriptions. Neither is it clear that he has in all places applied the name "Tonto sandstone" to the same formation. Attempts to identify in his published sections the formations discriminated in the Roosevelt and Grand Canyon sections have met with little success.

One of Gilbert's sections (No. IX, Aubrey Cliff, at Canyon Creek) interpreted in the light of present knowledge of Arizona stratigraphy is given in the correlation chart of Plate XXV (p. 136). The original description is as follows:

1. Coarse uncemented gravel, of quartzite and Feet. gneiss bowlders.................... 20

2. Massive cross-bedded yellow sandstone....... 525

3. Compact gray limestone; Spirifer cameratus... $\quad 65$

4. Red and purple sandstone, soft at top, massive below..............................

5. Alternation of gray limestone and red shale:

a. Limestone, 5 feet.

b. Unseen; shale (?), 100 feet.

c. Limestone, Athyris subtilita, 10 feet.

d. Red calcareous sandstone, 4 feet.

$e$. Shale, 40 feet.

$f$. Limestone, 4 feet.

g. Unseen; shale (?), 25 feet.

$h$. Massive limestone, 10 feet.

$i$. Unseen; shale (?), 75 feet.

$j$. Limestone, 2 feet.

$k$. Unseen; shale (?), 50 feet.

6. Sandstone:
$a$. Brown to red, coarse vitreous sand- stone, massive to shaly, 100 feet.
$b$. Gray fine-grained sandstone, weath- ering red, falling apart in angular blocks, 75 feet.
c. Shaly calcareous sandstone, 75 feet.
d. Vitreous, red, purple, and white sandstone, 150 feet.
e. Coarse siliceous conglomerate, 25 feet.)

7. Hornblende rock and schists; unconformable. $\frac{500+}{2,360+}$

In this section No. 2 is unquestionably the Coconino sandstone, 3 and 4 are probably the 
Supai formation, although it is thinner than might be expected, 5 presumably is the Redwall, and 6 is possibly the Tapeats ("Tonto") sandstone, although it appears to be too thick for that formation. The section as a whole conforms to the Grand Canyon type and is decidedly different from the Roosevelt and Ray-Globe sections.

Gilbert ${ }^{1}$ gives a section on Carrizo Creek, which is about 20 miles east of Canyon Creek, that indicates the presence of 1,200 feet of Supai rocks above the Redwall, but his descriptions suggest that there may be some difficulty in determining the stratigraphic limits of the formations in this region. Another of his sections (No. XI) measured north of and near Fort Apache gives 1,390 feet that indicated diagrammatically in figure 12 The oldest formation seen in this traverse is the Dripping Spring quartzite. This forms the lower line of cliffs that are conspicuous along the west face of the rarge for 7 or 8 miles north of Salt River. It has been considerably faulted, so that in places isolated down-dropped blocks lie in front of the main escarpment, and has also been intruded by diabase. The bottom of the quartzite was not seen, but the beds exposed were estimated to have a thickness between 300 and 500 feet.

Above the quartzite is an enormous sill of diabase probably 1,000 feet or more in thickness, dipping to the east, like the quartzite, at $10^{\circ}$ to $15^{\circ}$. In consequence of its greater susceptibility to decomposition and erosion, the

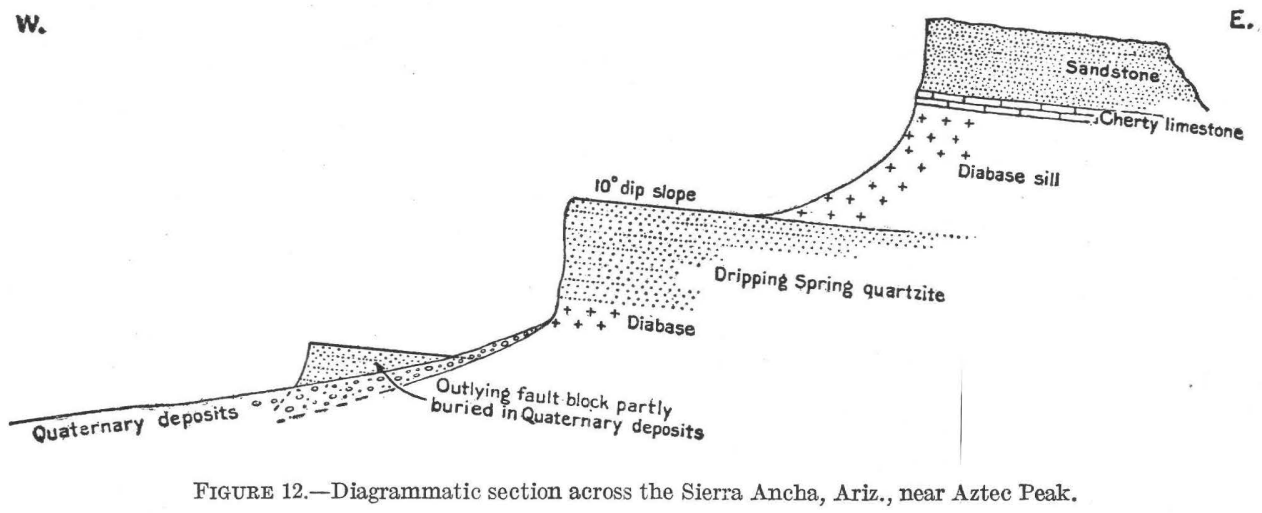

of beds that from his description would probably now be identified as the Supai formation.

\section{SIERRA ANCHA AND MAZATZAL RANGE.}

CARR'S RANCH AND VICINITY.

The western front of the Sierra Ancha, as seen from Roosevelt, is bold and precipitous. Even so distant a view reveals very clearly the general structure of the range- that of a block, probably a fault block, uptilted along its western margin. Dark cliffs of red-brown quartzite in the lower part are succeeded along the crest by beds so much lighter in hue that they suggested at first the presence of the Carboniferous limestones.

An ascent of the range was made from Roosevelt in 1914 by way of Carr's ranch to Aztec Peak, and its general structure was found to be

1 Gilbert, G. K., op. cit., p. 164. diabase has weathered back, leaving a broad dip-slope bench on the quartzite, which is followed for many miles by the road from Salt River to Carr's ranch. (See fig. 12.) Ravines leading down from the upper part of the range cross this bench and in the quartzite become deep, narrow chasms with vertical walls. A few included masses of altered Mescal limestone were noted in the diabase, and remnants of the limestone appear to overlie the igneous rock in some places. Evidently here, as in the Globe-Ray region, the principal diabase intrusion took place at the Mescal horizon.

Carr's ranch is situated on the diabase sill at an elevation of about 5,600 feet. A few miles northeast of the ranch on the north side of Workman Creek, a section of the beds that overlie the diabase was examined. The results are as follows, the thicknesses having been determined by aneroid barometer. 
Top of ridge.

Section in Sierra Ancha.

8. Hard white quartzitic sandstone, with streaks of well-rounded quartz pebbles, none of which are over 2 inches in diameter. Weathers light red or pinkish brown. Beds 5 to 6 feet thick near base but stratification less distinct above. Some cross-bedding at low angles. Forms a cliff

7. Fairly hard coarse to pebbly pink-buff sandstone. Grains smaller than peas. Grades downward into No. 6

6. Massive, generally fine-grained gray sandstone. Weathers dingy white and forms a rough ledgy slope above cliff noted below. Fairly soft and could be easily worked as a building stone. Texture uneven, owing to imperfect mixing of grains of different size....................

5. Massive fine-grained pink to buff sandstone. Forms a cliff. Contains well-rounded grains of pink feldspar and white quartz, the largest the size of mustard seeds. Layers of quartz pebbles as much as 2 feet thick in upper 100 feet. Pebbles fairly well rounded and 4 inches or less in diameter, in places scattered through the sandstone...........................

4. Fine-grained homogeneous pinkish sandstone. Bedding not distinct. Weathers in slabs and as a rule forms a steep slope..................

3. Fine-grained red-brown, rather flaggy sandstone. Rests directly on basalt. Contains flakes and thin layers of red shale..................

2. Vesicular basalt flow, forming a red-brown bluff. Thickness not closely determined, probably about..............................

1. Thin-bedded cherty limestone, considerably metamorphosed and containing serpentine, tremolite, and pyrite. Not well exposed. Thickness uncertain, probably about.......... Intrusive diabase at base.

From the top of this section to the summit of Aztec Peak, on Baker Mountain, the difference in elevation is about 200 feet. This interval appears to be occupied by a massive medium-grained quartzitic sandstone, on which weathering brings out a lamination parallel with the bedding. In places this sandstone is rusty and contains little ball-like concretions an inch or two in diameter. Although no unconformity was detected, the possibility of a stratigraphic break between this sandstone, or some part of it, and the sandstones noted in the preceding section can not be denied.

The metamorphosed limestone above the diabase at the base of the section is probably the Mescal limestone. Above it is at least 900 feet of sandstone, which is supposed to be the stratigraphic equivalent of the Troy quartzite.

\section{GREENBACK VALLEY AND VICINITY.}

About 9 miles west-northwest of Carr's ranch, also on the west slope of the Sierra Ancha, is Greenback Valley, a little basin about 2 miles in diameter; floored chiefly with diabase and inclosed in part by cliffs of Dripping Spring quartzite. The quartzite, as in parts of the Globe-Ray region, has been extensively invaded by the diabase, both as thick sheets and as crosscutting masses. In places blocks of the quartzite strata were evidently at one time completely enveloped in the diabase magma.

The basal rock in this vicinity is a coarse porphyritic biotite granite. This is exposed in the deep gorge of Sallymay Creek, 5 miles east of the valley, and at several places along the west base of the range between Greenback Valley and Tonto Creek.

Resting upon the granite on Sallymay Creek is a basal conglomerate about 6 feet thick where seen. The lower 3 feet is coarse, with well-rounded pebbles of white quartz, pink quartzite, and red jasper, the largest 8 inches in diameter, in an arkosic matrix. Overlying the conglomerate is a brownish-red arkosic quartzite containing abundant particles of pink feldspar. Between some of the quartzite beds are thin layers of sandy shale. This quartzite is probably the stratigraphic equivalent of the Pioneer shale farther south. It is at least 150 feet thick and may be considerably thicker. Overlying it is a sheet of diabase, on top of which is the cliff-making Dripping Spring quartzite. Whether the Barnes conglomerate is present above or below the diabase on Sallymay Creek was not ascertained in the short time spent in this locality.

Just north and east of Greenback Valley the range exhibits well the generally broad-topped character which originally suggested its Spanish name. From the brink of the westwardfacing cliffs the surface slopes gently eastward, much of it being a dip slope on the tops of the Dripping Spring quartzite. Here and there are remnants of thin-bedded cherty limestone, presumably the Mescal limestone. The top of Greenback Mountain, east of Greenback Valley, is such a remnant.

On the north slope of Chubb Mountain, near the point where a trail from Greenback Valley descends a very steep slope into the 
canyon of Sallymay Creek, the diabase is overlain, with igneous contact, by a little pink quartzite, which is succeeded conformably by 15 to 20 feet of hard conglomerate. This closely resembles the typical Barnes conglomerate, but here, as in other places near Greenback Valley, the Dripping Spring quartzite and older formations have been so broken and displaced by the diabase intrusion that it is not always possible to be sure of the stratigraphic relations without much more detailed work than can be done in a hasty reconnaissance.

From Clanton's ranch, on Tonto Creek, about $4 \frac{1}{2}$ miles above Cline, another traverse was made to the crest of the Sierra Ancha, which was reached at a point 4 miles north-northwest of Greenback Valley and 7 miles southeast of Gun Creek. The western slope of this part of the range was found to consist of numerous fault blocks, each consisting of the basal granite, Scanlan conglomerate, Pioneer shale, Barnes conglomerate, and Dripping Spring quartzite, with great sills of diabase, all lying nearly horizontal. The faults are apparently normal and form a series of steps leading to the crest of the range, which at the locality visited is a plateau nearly 6,000 feet in altitude, corresponding to the upper surface of the Dripping Spring quartzite and surmounted by a few patches of cherty limestone, probably the Mescal. The Scanlan conglomerate is 5 to 6 feet thick and is made up of fairly well rounded pebbles as much as 8 inches in diameter. It rests on the same coarse red granite that is seen in Sallymay Canyon. Above the Scanlan conglomerate is some typical Pioneer shale, but higher in the section the shale becomes interbedded with quartzite, and, as the Barnes conglomerate does not appear to be strongly developed, the plane between the Pioneer shale and the Dripping Spring quartzite was not very satisfactorily determined in the short time given to the examination. The Pioneer formation is probably not over 200 feet thick in this part of the range. The Dripping Spring quartzite, however, is prominently developed and generally forms a horizontally banded redbrown cliff. It has a local thickness of about 500 feet.

From Roosevelt northward the valley of Tonto Creek, deeply filled with fluviatile and $30830^{\circ}-17-11$
Iacustrine deposits, is 4 or 5 miles in breadth and contains a recent alluvial flood plain a mile or so wide along the creek. Near the mouth of Gun Creek this valley contracts to a gorge in schist and a sharp ascent of about 500 feet over hills of pre-Cambrian schist leads up to Tonto Basin. This is an irregular depression whose hilly floor, ranging from 3,000 to 6,000 feet in altitude, is bounded very definitely on the north by the great escarpment of the Mogollon Mesa and is less completely closed in on the west by the linear crest of the Mazatzal Range and on the southeast by the northern part of the Sierra Ancha. The floor of the basin is composed mainly of granite and other pre-Cambrian intrusive rocks, with some schist, covered in part by Tertiary and Quaternary volcanic rocks and gravels.

\section{DELSHAY BASIN.}

Delshay $^{1}$ Basin is a well-marked upland depression, about 3 miles in diameter, on the west slope of the Sierra Ancha near the north end of that range. It is drained through deep canyons by Gun Creek and its tributaries. The basin, whose floor has a general altitude of 4,500 to 5,000 feet, is best reached by road and trail from Hardt's ranch, in Tonto Basin.

The fundamental rocks between Hardt's ranch and Delshay Basin are crystalline sericitic and greenstone schists, which strike in general northeast and dip northwest at high angles. These are cut by dikes of granite porphyry and of rhyolite that is in places schistose. A bold ridge of the schistose rhyolite forms the west wall of the basin, and Gun Creek flows in a wild gorge along its eastern base. Closely associated with the schist are masses of quartzite that lie unconformably beneath the nearly horizontal Cambrian quartzites and are described on pages 157-159. Some beds of magnetitic quartzite, striking northeast, form part of the schist series in Delshay Basin, and occupy a belt perhaps a quarter of a mile wide and at least a mile in length. The deposits appear to be lenticular, and the individual masses are 50 feet in maximum width. There are all gradations between nearly pure magnetite and dark ferruginous quartzite.

1 This name, in use by the cattlemen of the region, is said to be that of a former Indian chief. Some uncertainty attaches to the spelling, which is that given to me at Hardt's ranch. 
The material was evidently laid down in preCambrian time as a magnetitic sand and has been folded and squeezed with the other rocks of the schist complex.

Southeast of the magnetite belt in Delshay Basin is a belt from 1 to 2 miles wide of a peculiar conglomerate that is clearly a part of the schist complex, has been thoroughly squeezed, and is decidedly schistose. The cleavage planes stand nearly vertical. The "pebbles" are mostly flat flakes of slate and schist, as much as 8 inches long, with a few round pebbles of harder material. The matrix consists of grains of quartz and pink feldspar. Clearly the schistose terrane in this region has a complex history and records more than one period of dynamic metamorphism. To the east of the schist conglomerate Delshay Basin is floored with coarse red pre-Cambrian granite. Presumably the schist conglomerate was originally deposited on this granite, but the contact was not seen.

On the east and south the rocks that have been mentioned as exposed in the floor of Delshay Basin are overlain unconformably by nearly horizontal beds, whose edges are exposed in the steep slopes and cliffs that shut in the basin on those sides. A section of these beds up the east wall of the basin is as follows, the thicknesses being approximate only:

Section on east side of Delshay Basin.

Crest of Sierra Ancha.

13. Purplish brown calcareous shale, apparently interbedded with impure cherty limestone. Slope littered with rusty spongy chert....... 125

12. Smooth slope with no exposures. Fragments of thin-bedded rusty sandstone and shale with some very impure dolomitic limestone. Abundant fragments of dark vesicular chert. A little decomposed igneous material. Small outcrop of light gray limestone at base...............

11. Smooth slope with few outcrops. Rusty cherty detritus in soil, with fragments of thin-bedded sandstone and shale......................

10. Fine-grained, rather rusty quartzitic sanästone. Beds a little thicker than in No. 9, the maximum being 3 feet...................... 100

9. Thin-bedded flaggy sandstone with some shale. Weathers in buff, brown, and rusty shades. Some beds show worn casts. Forms gentle slope with poor exposures................ 100

8. Massive pink quartzitic sandstone, weathering with pits like No. 6. Prominent cliff maker...

7. Fine-grained pink to yellow-brown quartzitic sandstone. Like No. 6 , but in thinner beds; forms slope............................
6. Massive pink quartzitic sandstone with, in lower part, a few rather angular pebbles of white quartz as much as 4 inches in diameter. Prominent cliff maker. Weathers with numerous round but rather irregular pits, mostly less than 1 inch across............................

5. Conglomerate with rather angular pebbles of white quartz. Thickness apparently variable, where seen about.............................

4. Massive fine-grained red-brown sandstone. Beds 12 feet or more thick, but bedding inconspicuous. Some cross-bedding at low angles, not over $30^{\circ}$. Less noticeably arkosic than beds below. Forms cliffs....................... 150

3. Apparently fine-grained red-brown sandstone. Exposures in part poor or lacking............. 100

2. Coarse red-brown arkosic, quartzitic sandstone in beds as much as 6 feet thick. Contains illdefined layers of conglomerate with pebbles mostly under $1 \frac{1}{2}$ inches and not well rounded. Some layers of spotted red shale............ 150

1. Conglomerate with poorly rounded pebbles of white quartz in a coarse arkosic matrix. Pebbles mostly. under 2 inches...................

(This conglomerate is apparently better developed and has larger pebbles in neighboring parts of the same ridge, as indicated by blocks in streamways.)

Bottom of section coarse red granite, of which upper 4 or 5 feet appears to have been disintegrated before overlying sediments were laid down.

The foregoing section is not readily divisible into the units of the Globe-Ray section, and evidently the changes that take place in the older Paleozoic sediments along the Sierra Ancha require something more than a few traverses to determine their character and significance. A careful stratigraphic study carried continuously along the range would undoubtedly yield interesting results. Nevertheless, it is believed that the section given is much more closely related to the Globe-Ray section than to the sections farther north that will presently be described. The thin-bedded impure cherty limestone at the top of the section is probably the stratigraphic equivalent of the Mescal limestone, and the sandstones and conglomerates below probably represent the Scanlan conglomerate, Pioneer shale, Barnes conglomerate, and Dripping Spring quartzite. The great intrusions of diabase are not represented in the part of Delshay Basin seen, and the absence of this rock may account for the fact that the arenaceous beds are less quartzitic than farther south and lack certain other 
features that are characteristio of these rocks in the southern part of the range, at Roosevelt and in the Globe-Ray region.

\section{PRE-CAMBRIAN SEDIMENTS OF THE NORTHERN SIERRA ANCHA AND OF THE MAZATZAL RANGE.}

One of the most interesting of the results of the two reconnaissance trips made into the region adjacent to Tonto Basin was the recognition of a thick series of quartzites, conglomerates, and shales that is unconformably beneath the Apache group and its stratigraphic equivalents. A brief reference to these rocks has already been published. ${ }^{1}$

The unconformity between these pre-Cambrian strata and the nearly horizontal Paleozoic beds is clearly shown just north of Delshay Basin. Here a prominent bold hill lying just east of Gun Creek and north of a tributary that is locally known as Sheep Basin Draw is composed of this older quartzite. The rock was not closely examined at this locality, but the beds are evidently some hundreds of feet in total thickness and are complexly folded and faulted. Just east of this hill, which closes Delshay Basin on the north, are the cliffs in which are displayed the nearly horizontal beds described in the section on page 156. These beds were not seen at this locality in actual unconformable contact with the older quartzite, but the contrast in character and structure is so obvious that no doubt is entertained of the existence of a pronounced unconformity. The relation of the older quartzite to the schist terrane is apparently intimate, and the quartzite has shared to some extent in the vigorous deformation to which the schistose rocks have been subjected.

The pre-Cambrian strata occur also in the northern part of the Mazatzal Range and were here more closely examined. Mazatzal Peak, about 8,000 feet in altitude, is composed chiefly of these rocks, which appear to constitute the higher portion of the range from this rugged summit northward.

From Hardt's ranch a traverse was made up Deer Creek, which heads south of Mazatzal Peak and flows eastward into Rye Creek, a tributary of Tonto Creek. The lowest and oldest rocks exposed on Deer Creek are schists.

${ }^{1}$ Ransome, F. L., Quicksilver deposits of the Mazatzal Range, Ariz.: U. S. Geol. Survey Bull. 620, pp. 114-117, 1915 (Bull. 620-F).
These schists, with those exposed at Hardt's ranch and in Delshay Basin, are part of a northeasterly belt that crosses the Mazatzal Range obliquely between the pre-Cambrian granite of Mount Ord and the quartzite mass of Mazatzal Peak and apparently continues northeastward past the north end of the Sierra Ancha. The descriptions given by Reagan ${ }^{1}$ are not quite clear on this point, but the belt of schistose rocks, irregularly overlapped in places by younger formations, appears to extend eastward across the upper parts of Cherry, Canyon, and Cibicu creeks, beyond which it probably passes under the horizontal Paleozoic beds of the Arizona Plateau. Where seen in the Tonto region these schists have considerable lithologic variety. They include sericite schist, greenstone schist, brown and dark-gray slates, schistose grits and conglomerates, hematitic schist, thin-bedded dolomite and red jasper, and beds of quartzite or quartz schist. Associated with these rocks are some rhyolite, generally schistose in part, and small masses of other ancient igneous rocks. Where it crosses the Mazatzal Range the belt of exposures is about 5 miles wide. To the northeast, where it crosses Tonto Basin and extends past the north end of the Sierra Ancha, the area of schistose rocks is probably at least 15 miles wide. The belt contains the quicksilver deposits of the Mazatzal Range. ${ }^{2}$ It is of especial interest in connection with the subjects discussed in the present paper, as it appears to mark a pronounced change from north to south in the character of the pre-Devonian Paleozoic sections of this part of Arizona. This will be brought out more fully in subsequent pages.

At an altitude of about 5,600 feet on the north side of the middle fork of Deer Creek the basal bed of the pre-Cambrian sedimentary beds rests on red oxidized rhyolite that shows well-developed flow structure. The relation of this old rhyolite to the schists was not ascertained, but it is probably a part of the schist complex. The beds strike N. $33^{\circ}$ E. and dip about $70^{\circ} \mathrm{NW}$. This attitude agrees fairly well with the general strike and dip of the schists and suggests that the beds about to be

1 Reagan, A. B., Geology of the Fort Apache region in Arizona: Am. Geologist, vol. 32, pp. 265-308, 1903.

2 Ransome, F. L., Quicksilver deposits of the Mazatzal Range, Ariz : U. S. Geol. Survey Bull. 620, pp. 111-128, 1915 (Bull. 620-F). 
described have taken part in at least some of the pre-Cambrian deformation to which the schists have been subjected.

At the base of the sediments is a brick-red detrital rock made up of flakes' of schist in an abundant matrix, apparently also composed of minute schist particles with an occasional grain of quartz. The material suggests an indurated oxidized stony soil. It is about 80 feet thick. Overlying it without any sharp plane of demarcation is a conglomerate about 2 feet thick, with rather sparse pebbles of rhyolite and red jasper as much as 5 inches in diameter. The conglomerate in turn grades upward into quartzite. The quartzite is very hard and vitreous and is generally reddish or brown. Much of it is banded parallel with the bedding planes. Little seams or films of specularite on joint planes are rather characteristic.
The first rock to be seen in ascending the ravine is a large body of quartzite folded into a sharp anticline and apparently faulted against shales on the northwest. These shales resemble nothing I had previously seen in Arizona. They are gray-green, weathering yellow, fairly hard, and only moderately fissile, and they effervesce in acid when powdered. Evidently they are somewhat dolomitic. For about 50 feet from their top they alternate with thin beds of quartzite and conglomerate. The conglomerate layers are less than a foot thick and carry pebbles of quartz and red jasper. The strike of the shales where seen is northeast and the dip northwest at $55^{\circ}$ in the bottom of the canyon and at $45^{\circ}$ near the top of the formation. The stratigraphic base of the shale was not seen, but the apparent total thickness of the beds exposed was very roughly estimated at 1,000 feet.

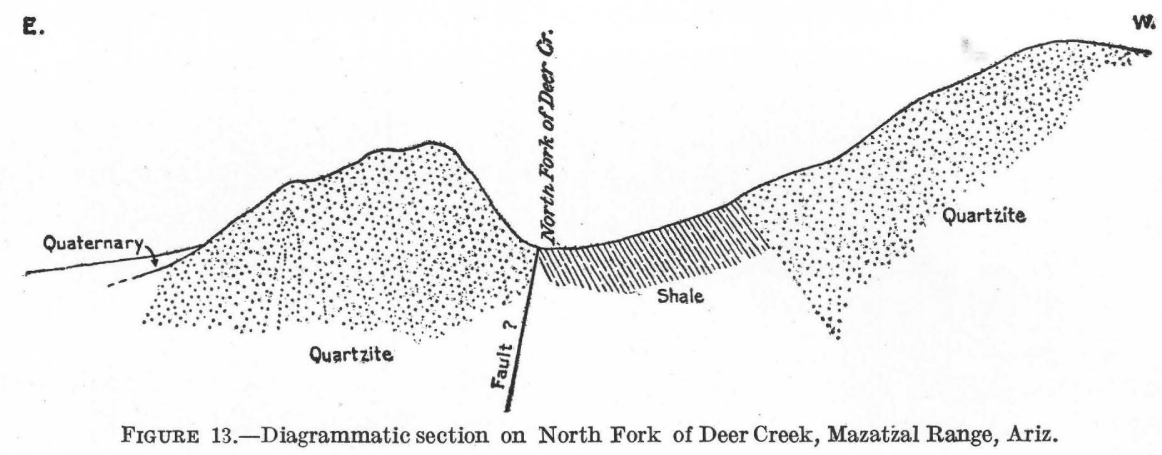

Between many of the beds are thin partings of hard red micaceous shale showing worm casts. These beds were found to continue up the precipitous slope to an altitude of 6,500 feet, but at that point the traverse had to be abandoned. The apparent thickness is at least 1,400 feet, but there is possibly some duplication of folding or faulting. Similar quartzitic beds were observed to continue some hundreds of feet higher, to the crest of the ridge, and quartzite with blocks of coarse grit or fine conglomerate were the only rocks observed in the talus. The pebbles in the conglomerate are as a rule smaller than peas and consist mostly of quartz and red jasper.

Another traverse was made up the North Fork of Deer Creek. The relations there seen are indicated in the rough sketch shown as figure 13. This is not drawn to scale and no attempt was made to measure the thicknesses of the beds.
The shale is overlain, with apparent conformity, by hard brown quartzite in beds generally less than 2 feet in thickness. The dip grows less toward the top of the slope, and at an elevation of 700 feet above the north fork the beds lie in gentle folds with dips of $25^{\circ}$ and less. The quartzite beds vary in color, but most are reddish. Layers of small pebbles of quartz and red jasper are fairly abundant.

The same pre-Cambrian quartzites described as occurring in the vicinity of Deer Creek and Mazatzal Peak appear to continue along the crest of the Mazatzal Range to its northern termination at North Peak, the base of the range being schist, granite, and probably other ancient crystalline rocks.

The northernmost point at which the preCambrian sediments have been recognized in this part of Arizona is on Pine Creek, in the vicinity of Natural Bridge, about 8 miles northwest of Payson and 12 miles north of North 
Peak. At Natural Bridge, where Pine Creek escapes past an obstructing terrace of travertine, partly by a narrow gorge of wild beauty and partly through a lofty natural tunnel under the calcareous mass, the nearly horizontal Paleozoio limestones and the basal Cambrian sandstone (Tapeats?) are exposed on the east side of the stream, which has cut through them into the granite. On the west side of the creek is a precipitous slope, 400 to 500 feet high, in which are exposed coarse red granite, overlain by a coarse granitic conglomerate, with bowlders as much as 2 feet in diameter, which in turn is overlain by hard cross-bedded reddish quartzite with layers of conglomerate. These beds dip about northnorthwest at an angle estimated at $55^{\circ}$, and are disturbed by faulting. The general relations of the beds at Natural Bridge are dia- monadnock on a surface so nearly worn down to a plain as that over which the arenaceous deposits of the Cambrian sea were spread for thousands of square miles, it is still more difficult to account in any other way for this island-like mass of indurated tilted strata surrounded by dissimilar, nearly horizontal, and apparently younger beds. Moreover, these older beds are much more resistant than the granite, and the fact that here and there eminences of hard rock projected above the general level of the vast pre-Tonto floor and were not finally buried until long after the deposition of the Tapeats sandstone is visibly evident in the walls of the Grand Canyon.

Natural Bridge is one of the few places in the region where good accommodations can be had for man and beast, and the locality would well repay more careful study than

E.

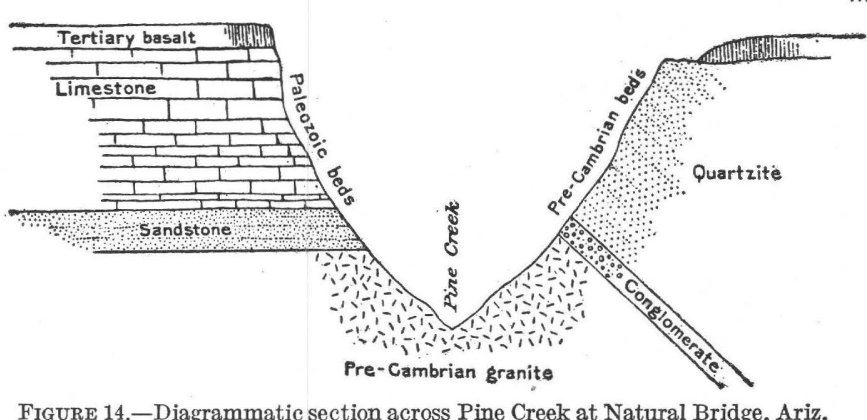

grammatically indicated in the rough sketch of figure 14. The coarse conglomerate and arkose conglomeratic quartzite on the west side of the creek at Natural Bridge are apparently older than the sandstone and overlying limestone on the east side and are part of a steep ridge that rose above the general level of the granitic surface upon which the basal sandstone (Tapeats ?) accumulated. This ridge can be traced in a north-northeasterly direction from Natural Bridge for about 4 miles, to a point east of Pine, where it passes under the horizontal strata of the plateau. About $2 \frac{1}{2}$ miles southeast of Pine, on the road to Payson, the nearly horizontal limestones above the Cambrian sandstone abut unconformably against the slope of this old ridge and locally contain angular fragments of the older quartzite.

While it is difficult to understand the survival of a small sharp ridge as an isolated could be given to it in the course of the hasty reconnaissance made in 1912 。

\section{JEROME GEOLOGIC SECTION, WITH NOTES ON STRATIGRAPHY BETWEEN PAYSON AND JEROME.}

The geologic column given in Plate XXV as the Jerome section is really a composite, only the part below the Supai formation having been measured at Jerome. The higher beds, however, are well exposed in the escarpment of the plateau a few miles north of the town and along the route from Payson to Camp Verde by way of Fossil Creek. The thicknesses given for the Supai and Coconino formations were obtained by rough aneroid measurements on Fossil Creek and at the head of Pine Creek.

An excellent section of the lower part of the local geologic column is exposed where the road from Payson to Pine crosses East Verde 
River. At the base is coarse red granite. Upon this rests horizontally 80 feet of dull red-brown cross-bedded pebbly sandstone. Cliff faces show some irregular horizontal lamination but no distinct divisional planes, and the whole forms a single thick bed. Few of the included pebbles are over an inch in diameter. Overlying the massive bed are thinner-bedded pebbly sandstones grading upward through a thin layer of shale to limestone. The thinner sandstone beds have a thickness of 30 feet, making the total thickness of the basal sandstone 110 feet. As will be shown later, there can be no reasonable doubt of the identity of this sandstone with the Tapeats ("Tonto") sandstone of the Grand Canyon section.

The following section of the overlying limestone was measured by aneroid a short distance west of the river, where the limestone is capped by Tertiary or Quaternary basalt. The numbers correspond to those used in the Jerome section on Plate XXV (p. 136).

\section{Section of limestone near East Verde River.}

Basalt.

8. Rather thin-bedded, in part flaggy light-gray compact limestone, with a few thin beds of Feet. sandstone near top.................... 130

7. Pink and gray sandy limestone.............. 50

6. Hard, compact gray limestone in beds 2 to 3 feet thick

5. Red shale, with bed of laminated gray quartzite, 2 to 3 feet thick at the top..................

4. Thin-bedded gray limestone. For 25 or 30 feet above the Tapeats sandstone this is flaggy and somewhat sandy. Grades upward into compact, hard light-gray and pink limestone.

Tapeats sandstone.

No fossils were found in these beds, but the limestones are probably, in part at least, Devonian. It is to be noted that the Bright Angel ("Tonto") shale of the Grand Canyon is not represented on the East Verde.

The beds underlying the little alluvial valley at Pine appears to belong to the lower part of the Supai, and higher strata of the same formation crop out as a broad rosy band along the cliffs north and east of the village. As a rule this strip of bright color blends rather indefinitely into the buff tint of the overlying Coconino sandstone, which is the cliffmaker of this part of the plateau edge. An aneroid measure- ment of the Coconino sandstone at the head of Pine Creek showed that the Coconino is at least 500 feet thick. It is a fine-grained, remarkably homogeneous, and rather soft sandstone, whose constituent quartz grains sparkle brilliantly in the sunlight. The color generally is pale buff to nearly white, but it weathers in more or less rusty tints near the base. Cross-bedding as a rule is more conspicuous than bedding and the rock splits more readily along the obique laminations than it does parallel with the true bedding.

About 6 miles west of Pine the mail trail between Payson and Camp Verde crosses the canyon of Fossil Creek $^{1}$ and affords a fairly good section of the Supai formation, which here consists chiefly of bright-red friable, very fine grained calcareous and gypsiferous sandstones, with a few beds of soft light-gray sandy limestone. One bed of such limestone, about 20 feet thick, is well exposed on the trail about 50 feet below the east rim of the canyon and is regarded as the topmost bed of the Supai. About 800 feet below this bed is a layer of gray limestone conglomerate, about 12 feet thick, with pebbles of limestone as much as 2 inches in diameter. A seam of very impure lignite, reported to be in places 20 inches thick, lies just under this conglomerate and is said by prospectors to be accompanied by some native copper. The barometric readings on this section gave a thickness of about 1,250 feet for the Supai formation, but this is probably a little high, and an estimated thickness of 1,000 feet is used in the Jerome section ( $\mathrm{Pl}$. XXV). The Supai beds are locally very soft and generally form steep ruddy slopes under the pale-buff cliffs of the Coconino sandstone. The distinction between the two formations, as seen in cliff faces, is not sharp, as there are some soft reddish beds above the 20-foot gray limestone. Likewise at the base there is some gradation of the red beds into the rather thin bedded gray limestones, presumably Redwall, exposed in the bottom of Fossil Canyon.

Between Fossil Creek and Camp Verde the sedimentary rocks are buried under heavy flows of basalt, with intercalated layers of tuff, which apparently are younger than the extensive lacustrine deposits, consisting of

1 This creek owes its name to the incrusting action of some copious springs which, after building up a huge terrace of travertine, now issue from the base of the mass, on the edge of the stream. 
gypsiferous clays, limestone, gypsum, and salt and probably over 1,000 feet thick, that fill this part of the Verde Valley.

The town of Jerome is west of and about 1,500 feet above Verde River, at the north end of a short range known as the Black Hills. The prospect northeast from Jerome probably surpasses in beauty and geologic interest anything else to be seen in Arizona, except the unrivaled Grand Canyon. From 4 to 6 miles distant, across a belt of relatively low hills whose pale hue proclaims the Redwall limestone, meanders the Verde with its narrow fringe of trees and green fields. Beyond the river, 15 miles away, is the great scarp of the plateau, here thrusting a bold promontory into the valley, there retreating in some shadowy recess where a creek has cut back into the table-land, and glowing along its entire front with the ruddy warmth of the Supai, which shades upward into the creamy tints of the Coconino sandstone and downward into the whiteness of the Redwall. Finally, 50 miles away, beyond the pine forest whose fringe darkens the top of the cliff, the even sky line of the plateau is boldly surmounted by the volcanic mass of the San Francisco Mountains, upon whose crest the snow yields but slowly to the heat of summer. Nor is it necessary to look to these distant peaks for evidence of volcanic activity in recent geologic time. Dark flows of basalt, at various levels, cap parts of the plateau and outlying mesas, much nearer at hand, and only a few miles north of Jerome, Verde River has barely succeeded in cutting through a lava stream that usurped its channel.

The rocks of the Black Hills have undergone some of the deformation which is so characteristic a feature of the mountain region and which gives it a structure and topography so different from that of the plateau, here in plain sight for comparison. The most conspicuous element of the structure near Jerome is a fault that strikes N. $30^{\circ} \mathrm{W}$. and dips about $60^{\circ} \mathrm{NE}$. The dislocation is of the kind classed as normal, and the throw at Jerome is roughly estimated at about 1,300 feet. The result of the movement has been to elevate the Black Hills. relatively to the plateau country, to expose the pre-Cambrian schists southwest of the fault, and incidentally to bring to light the great body of copper ore now worked by the United Verde Copper Co.

Resting upon the schists on the hillside just west of the United Verde mine is the Tapeats sandstone, 75 to 80 feet thick. It is locally a very dark red cross-bedded pebbly sandstone in which the pebbles, for the most part collected into lenticular layers, are rarely over 1 inch and mostly under half an inch in diameter. The dark rusty hue of the sandstone is probably due to ferruginous gossan material, derived from the pre-Cambrian pyritic deposits in the schist.

Conformably above the sandstone are lightyellowish, very compact limestones in beds from 2 to 3 feet thick and containing only obscure traces of fossils. These beds resemble the compact limestones of the lower part of the Martin limestone at Ray. This part of the formation, about 150 feet thick, is overlain by darker-gray limestones, some of which are sandy. Fossils are fairly abundant in these strata, but are as a rule poorly preserved and extremely difficult to collect. About 350 feet above the base of the limestone a light-gray bed about 5 feet thick, sandy in its lower part, but grading upward into a purer and more compact limestone, carries abundant small poorly preserved shells near its base and corals in its upper part. Fossils collected from this bed and those just above it were submitted to Dr. E. M. Kindle, who has identified the following species:

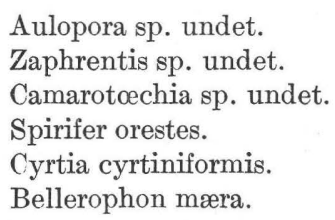

Mr. Kindle writes: "These species represent an Upper Devonian fauna of the same general facies as that previously collected by you at various points in Arizona." In other words, $i_{t}$ is the fauna of the Martin limestone. The total thickness of the beds provisionally assigned to the Devonian at Jerome is about 500 feet. Of course there is a possibility that the lower compact limestones, from which no fossils were obtained, may be older than Devonian. There are no beds present in the local section, however, that can be referred to the Bright Angel shale. 
Above the comparatively thin-bedded and impure Devonian limestone are thicker beds of white limestone, much of which is granular and contains abundant fragments of crinoid stems. This limestone is about 250 feet thick near Jerome. Fossils collected from it were referred to G. H. Girty, who lists the following:

\author{
Zaphrentis sp. \\ Schizophoria swallowi Hall. \\ Chonetes illinoisensis Worthen. \\ Productus burlingtonensis Hall. \\ Avonia arcuata Hall. \\ Pustula aff. P. scabricula Martin. \\ Camarotœchia sp. \\ Spirifer centronatus Winchell. \\ Composita humilis Girty? \\ Euomphalus sp. \\ Bellerophon sp.
}

Schuchertella aff. S. chemungensis Conrad.

He states that the horizon is clearly lower Mississippian and that the fauna shows close affinities with the Burlington, especially with the lower Burlington. This is unquestionably the Redwall limestone. The two lithologic divisions noted by Lee farther northwest are not apparent at Jerome, unless the beds here grouped with the Devonian correspond to the lower, thin-bedded part of the Redwall as described by Lee. ${ }^{1}$ No evidence was obtained at Jerome to indicate that any of the Redwall limestone is as young as the Pennsylvanian. In the Black Hills, the Redwall limestone is overlain by the red Supai beds which in turn are capped by basalt and are not present in full thickness.

Near the mouth of Sycamore Creek, 8 miles north of Jerome, fully 450 feet of limestone is exposed below the Supai. At the base of the Supai is a limestone conglomerate 2 to 3 feet thick in which the pebbles are generally less than 2 inches in diameter. Layers of similar conglomerate also occur a little higher in the formation. At this locality the lower 700 feet of the Supai consists chiefly of fine-grained cross-bedded sandstone in beds less than 6 feet thick, with a smaller proportion of deep red shale. The general color is not brilliant, and some of the sandstone beds incline to a tawny hue. The upper beds of this division of the formation are fairly massive and form an outer bench in the plateau escarpment at this locality. Overlying them

1 Lee, W. T., Geologic reconnaissance of a part of western Arizona: U. S. Geol. Survey Bull. 352, pp. 15-16, 1908. and under the Coconino sandstone are apparently softer beds of much brighter red, with an estimated thickness of 200 to 300 feet. As seen through field glasses at a distance of 2 or 3 miles they show conspicuous cross-bedding and appear to grade upward with no sharp break into the Coconino sandstone.

Gilbert ${ }^{1}$ has given a section at a locality described as " 15 miles southeast of Bill Williams Mountain." This apparently was measured on Sycamore Creek, some miles above its mouth. The section as given indicates the presence of 400 feet of Redwall limestone (base not seen), 600 feet of Supai (that is, 400 feet of "alternating fine-grained limestones and calcareous red and yellow sandstones," overlain by 200 feet of "friable red sandstone"), 700 feet of Coconino sandstone, and 335 feet of Kaibab limestone. overlain by basalt.

\section{GRAND CANYON GEOLOGIC SECTIONS.}

The general character and succession of beds in the Grand Canyon are too well known to geologists to require more than very brief description here.

In the section given by Gilbert ${ }^{2}$ for the mouth of the Grand Canyon the Tonto group, from the base up, is made to include the "Tonto sandstone" (now the Tapeats sandstone), 80 feet; the "Tonto shale" (now the Bright Angel shale), 600 feet; and the "marbled limestone" (now the Muav limestone ${ }^{3}$ ) 75 feet. Some uncertainty appears to exist as to the limits of the Muav limestone. Lee,${ }^{4}$ in his section measured a few miles west of the mouth of the Grand Canyon, describes the Tapeats sandstone as overlain by "about 600 feet of yellowish-green arenaceous shale," succeeded by the Redwall. In the Shinumo quadrangle Noble ${ }^{5}$ noted 450 to 475 feet of Muav limestone and only 25 to 375 feet of Bright Angel shale. $\mathrm{He}$ has separated as the Muav limestone beds that Gilbert and other observers considered to be part of the "Tonto shale," his Muav being the upper calcareous portion of the old "Tonto shale."

1 Gilbert, G. K., U. S. Geog. Surveys W. 100th Mer. Rept., vol. 3, p. 163, 1875 .

2 Idem, pp. 184, 196.

3 Noble, L. F., The Shinumo quadrangle, Grand Canyon district, Ariz.: U. S. Geol. Survey Bull. 549, p. 64, 1914.

${ }^{4}$ Lee, W. T., Geologic reconnaissance of a part of westorn Arizona; U. S. Geol. Survey Bull. 352, p. 15, 1908.

5 Op. cit., pl. 9. 
In the Kanab Valley, northwest of the Shinumo area, according to Walcott, ${ }^{1}$ there is 235 feet of "massive mottled limestone with 50 feet of sandstone at base" unconformably below the Devonian and above the "Tonto Primordial." This is probably the Muav limestone. In the portion of the canyon between the Bright Angel and Hance trails the Muar limestone, according to my own observations, is not conspicuously different, either in topographic expression or lithology, from the underlying shaly beds, and although the impure calcareous strata near the top of the Tonto group were not measured, they did not appear to be nearly so thick as was stated by Noble for the Muar limestone in the Shinumo quadrangle. Similarly Frach ${ }^{2}$ in his Congress Canyon section gives the Tonto group a thickness of 749 feet, of which the lower 290 feet is sandstone, leaving 459 feet for the generally snuff-colored shaly beds. He mentions the presence of some impure limestone in the upper part of the "upper Tonto," probably the Muav limestone.

The section given for the Kaibab district of the Grand Canyon region in Plate XXV (p. 136) is practically that given by Noble, ${ }^{3}$ the latest and probably the most accurate of the published sections of the Grand Canyon strata.

At the base of the stratigraphic column is the great wedge and smaller remnants of Algonkian beds named by Walcott ${ }^{4}$ the Unkar and Chuar "terranes" and more recently described in greater detail by Noble. ${ }^{5}$ The rocks composing the Unkar and Chuar groups include conglomerates, sandstones, shales, and limestones and are, owing to their variety, not easily characterized in brief. They are essentially fluviatile (deltaic) or shallow-water deposits, prevailingly red in the Unkar group and of more diversity of hue in the Chuar group. Lithologically the rocks of both groups have little resemblance to the lower formations of

\footnotetext{
1 Walcott, C. D., The Permian and other Paleozoic groups of the Kanab Valley, Ariz.: Am. Jour. Sci., 3d ser., vol. 20, p. 222, 1880.

a Frech, F., Section in Congress Canyon opposite Point Sublime: 5e Cong. géol. internat., Compt. rend., p. 479, 1893. Congress Canyon is apparently what is known as Red Canyon, through which runs the old Hance trail, and is far east of Point Sublime.

${ }^{3}$ Op. cit., pl. 9 .

${ }^{4}$ Walcott, C. D., Algonkian rocks of the Grand Canyon of the Colorado: Jour. Geology, vol. 3, pp. 312-330, 1895. (Gives references to his earlier papers on same subject.)

5 Noble, L. F., op. cit., pp. $40-53$.
}

the Globe-Ray and other sections to the south.

The Tapeats sandstone, 285 feet in maximum thickness, is generally a rather coarse crossbedded sandstone grading here and there into a pebbly grit. Lenticular layers of yellowish well-rounded quartz pebbles, the largest the size of peas, are very common. In contrast with the quartzites of the Algonkian, which commonly show conspicuous vertical jointing, the cliff faces of the Tapeats sandstone are characterized by a nearly horizontal banding, due to alternations of coarse and fine material. The usual color is buff, but in places this shades into dull red or maroon.

The Bright Angel shale, 375 feet thick, consists of fissile shales, for the most part micaceous, associated with thin beds of micaceous sandstone and impure limestones. The prevailing color is greenish yellow, and the formation generally weathers to a smooth slope. It has been carefully described by Noble. ${ }^{1}$ Fossils from this formation, including some wellpreserved trilobites obtained in 1911 near the Bright Angel trail, have been pronounced Middle Cambrian by Dr. C. D. Walcott.

The Muav limestone, according to Noble, ${ }^{2}$ is the predominantly calcareous upper part of the Tonto group and is 475 feet in maximum thickness. Since Bulletin 549 was written he has found fossils in the Muav limestone which, according to Edwin Kirk, of the United States Geological Survey, are of Middle or Upper Cambrian age. ${ }^{3}$

The Devonian Temple Butte limestone, 100 feet in maximum thickness, is in many places absent. Recent work of Mr. Noble, not yet published, supplies many details of its occurrence and of the unconformities between it and the overlying Redwall limestone and the underlying Muav limestone.

The massive Redwall limestone, from 600 to 700 feet thick, is overlain by the relatively thin-bedded red shales and sandstones of the Supai, 1,250 to 1,400 feet thick, followed by cross-bedded Coconino sandstone, 250 to 350 feet thick, and the pale-gray Kaibab limestone, 400 to 600 feet thick, containing Pennsylvanian fossils and extending to the brink of the canyon.

1 Noble, L. F., op. cit., pp. 62-64.

2 Idem, pp. 64-65.

3 Personal communication from L. F. Noble. 


\section{CORRELATION.}

In the comparison of the ten columnar sections shown in Plate XXV (p. 136) the most obvious stratigraphic plane of reference is the great unconformity at the base of the Cambrian. Another zone useful for correlation is that of the Devonian beds, which, in a northsouth belt extending through central Arizona, are made up persistently of limestone, are generally of moderate total thickness compared with the Cambrian and Carboniferous formations, and contain a characteristic fossil fauna, that of the Martin limestone of the Bisbee section. To the east, in the CliftonMorenci region, the Devonian beds consist chiefly of shale, this probably representing a gradation into the Percha shale of New Mexico. In the Grand Canyon region pre-Redwall erosion has in some places removed the Devonian beds, but they are present in a sufficient number of localities in the canyon, as has been shown by Noble, ${ }^{1}$ to establish their lithologic character and their place in the local section. At Jerome the Devonian limestone as represented in the columnar section of Plate XXV is thicker than in the more carefully studied sections to the south. Further examination may show that some of the lower beds provisionally included in the Devonian of the Jerome section belong to an older period.

It is with the correlation of the part of the geologic sections between the Devonian and the unconformity at the base of the Cambrian that the present paper is chiefly concerned. Comparison will first be made of this part of the Globe-Ray section with the corresponding part of the Bisbee section.

The lower parts of these two sections show decided differences. The Globe-Ray section includes the Scanlan conglomerate, the Pioneer shale, the Barnes conglomerate, the Dripping Spring quartzite, the Mescal limestone, and the Troy quartzite, with an aggregate thickness of 1,200 to 1,300 feet. At Bisbee there are the Bolsa quartzite, with some basal conglomerate, overlain by the Abrigo limestone, and the aggegate thickness is about 1,200 feet. In a general way the Bisbee Cambrian section resembles the Grand Canyon section, and it is not difficult to imagine the Bolsa quartzite as equivalent to the Tapeats (formerly the Tonto)

1 Noble, L. F., paper in preparation for publication. sandstone and the Abrigo limestone as €quivalent to the Bright Angel shale and Muav limestone (formerly both included in the "Tonto shale"). The probability of this exact equivalence is lessened, however, by the fact that the Bisbee and Grand Canyon sections are separated areally by the Globe-Ray section of a different type.

Fossils, considered by Dr. Charles D. Walcott to be Middle Cambrian, were found in the Abrigo limestone, but the supposed Cambrian portion of the Globe-Ray section has yielded no determinable fossil remains. Correlation by means of paleontology is therefore at present out of the question. Lithologically the Abrigo limestone and the Mescal limestone are in part identical, and as the beds showing this identity are of unusual character and maintain this character over large areas, the conclusion that the Abrigo and Mescal limestone are probably the same appears to be most nearly in accord with the facts. The striking similarity of the peculiar cherty limestone of the Abrigo and Mescal is shown by a comparison of Plates XXVIII and XXX.

If, as is likely, these two limestones are identical, then the Bolsa quartzite is equivalent to the Dripping Spring quartzite or to the Dripping Spring quartzite, Barnes conglomerate, Pioneer shale, and Scanlan conglomerate. In spite of metamorphism which has transformed the Pioneer shale locally to mica schist, the four formations just mentioned are recognizable in the Santa Catalina Range. Evidently, therefore, considerable change takes place within the 50 or 60 miles intervening between the Santa Catalina Range and Tombstone, where the section is of the Bisbee type. If the Abrigo and Mescal limestones are the same, then the Troy quartzite, about 400 feet thick in the Globe-Ray region, is represented at Bisbee by a bed of white quartzite, 8 feet thick, at the top of the Abrigo. ${ }^{1}$

The Clifton section is much like that at Bisbee. The Coronado quartzite is in all probability the same as the Bolsa quartzite. The Longfellow limestone, from Lindgren's descriptions, appears to resemble the Abrigo limestone in many respects and is probably, in part at least, equivalent to it. Fossils obtained from the upper part of the Longfellow

1 Ransome, F. L., Geology and ore deposits of the Bisbee quadrangle, Ariz.: U. S. Geol. Survey Prof. Paper 21, p. 32, 1904. 
limestone were determined by E. O. Ulrich to be of Ordovician age. ${ }^{1}$ As no fossils were found in the upper part of the Abrigo at Bisbee, the occurrence of the Ordovician fossils at Clifton does not preclude correlation of the two limestones.

North of the Globe-Ray region the preDevonian units of the Ray section are all recognizable at Roosevelt and in the Sierra Ancha. In the southern part of that range, however, the development of 1,100 feet or more of sandstone above the Mescal limestone makes correlation with the Troy quartzite rather uncertain. This sandstone appears to have the stratigraphic position of the Troy, but differs in lithologic character and is nearly three times as thick as that formation. The significance of this considerable change in the section in so comparatively short a distance as that between Roosevelt and Aztec Peak is not fully understood, and it is doubtful whether the beds of the Sierra Ancha section can ever be traced continuously into those of the Ray-Globe section. The only chance would be by way of the Apache Mountains, and the general structure and topography of the region makes it almost certain that there are gaps of many miles in which the Troy quartzite or its equivalent beds are not exposed or have been removed by erosion.

At the north end of the Sierra Ancha the section below what is supposed to be the Mescal limestone is not readily divisible into the units of the Globe-Ray section. Nevertheless it is believed to be more closely allied to that section than to those north of the Sierra Ancha.

From the north end of the Sierra Ancha to the vicinity of Payson there is a gap of about 15 miles in which the Paleozoic rocks are not present. This interval, as already described on page 157 , is occupied by pre-Cambrian crystalline rocks and by the pre-Cambrian quartzites, shales, and conglomerates that are well exposed in the Mazatzal Range. If the Grand Canyon series (Unkar and Chuar) is represented in the Tonto region of Arizona, it is without much doubt to be correlated with these older sedimentary beds and not, as some writers have suggested, with the unconformably overlying Apache group.

The last three sections given in Plate XXV are sections of the practically horizontal strata

1 U. S. Geol. Surrey Geol. Atlas, Clifton folio (No. 129), p. 4, 1905. of the Arizona Plateau and differ materially from those of the more disturbed rocks of the mountain region. This difference is strikingly apparent to one who, after studying the thick quartzitic sandstones of the Sierra Ancha, sees for the first time the sections near Payson, in which a comparatively thin basal sandstone is succeeded by limestones having no resemblance to the Mescal limestone. (See p. 160.) There is apparently little change in the character of the beds from Payson to the vicinity of Jerome, and the basal sandstone is, without much doubt, the Tapeats sandstone ("Tonto" sandstone) of the Grand Canyon section. The Bright Angel shale and Muav limestone, however, have not been identified at Jerome or at any locality southeast of that town.

The plateau sections differ also from those of the mountain region south of Payson in the development of the Carboniferous strata. In central and southern Arizona the Carboniferous is represented by great thicknesses of gray limestone that is not, as a rule, easily separable into Mississippian and Pennsylvanian portions. In the plateau sections there is a great development of sandstones and shales, and the Carboniferous deposits are divisible into the Redwall limestone, the Supai formation (red sandstones and shales), the Coconino sandstone, and the Kaibab limestone, named in ascending order.

Gilbert's Canyon Creek section, while distinctly of the plateau type, indicates considerable change in character east of Payson. It shows an increase in the thickness of the Cambrian sandstone and the absence of the Devonian beds through unconformity. No unconformity was noticed between the Devonian and Carboniferous at Jerome, but the study given to this section was too hasty to warrant the assertion that none is present.

The observations presented in this paper indicate that in Cambrian time a land barrier existed in the region now adjacent to Tonto Basin, between the depositional basin of central and southern Arizona and that now corresponding to the Arizona Plateau, or at least to that part of the plateau between Payson and the Grand Canyon. It follows that while the whole Apache group and its stratigraphic equivalents in eastern and southern Arizona were probably deposited at about the same time as the beds of the Tonto group, the beds of the two groups were probably never continuous within the Tonto region of Arizona. It can not 
be said that any particular sandstone or quartzite of the Apache group is identical with the Tapeats sandstone.

Although the evidence from fossils is lacking, it appears to be fairly well established that the entire Apache group is Cambrian, or possibly in part younger, and, so far as can be seen over a wide region, is conformably overlain by the Devonian, while in the northern parts of the Mazatzal Range and Sierra Ancha the Paleozoic beds overlie with conspicuous unconformity a series of shales, quartzites, and conglomerates which is probably equivalent to the Grand Canyon series.

The marked difference in the Carboniferous sections of the two geographic provinces in north-central Arizona suggests that the natural barrier supposed to exist in Cambrian time may have persisted in some form, possibly as a submarine ridge, throughout the Paleozoic era. 